\title{
RESERVE FLEET INDEXED TO EXOGENOUS COST VARIABLES
}

\author{
Hugo David NOGUEIRA RAPOSO ${ }^{1^{*}}$, José Manuel Torres FARINHA ${ }^{2}$, \\ Luís Andrade FERREIRA ${ }^{3}$, Diego GALAR ${ }^{4}$ \\ ${ }^{1,2}$ Centre for Mechanical Engineering, University of Coimbra, Portugal \\ ${ }^{3}$ Dept of Mechanical Engineering, Faculty Engineering University Porto, Portugal \\ ${ }^{4}$ Dept of Operation and Maintenance, University of Technology Luleå, Sweden
}

Received 19 June 2016; revised 1 May 2017, 7 June 2017; accepted 7 September 2017

\begin{abstract}
Identifying the optimal time to replace a passenger bus in a buses fleet has implications on the size of the reserve fleet. Such calculations rest on endogenous and exogenous economic variables: the former include operating and maintenance costs and bus depreciation; the latter include market imponderables such as the inflation and real discount rates, as well as energy costs, particularly fuel. The authors have created models for the withdrawal/replacement of buses using endogenous economic variables. The models include standard econometric models reflecting the influence of maintenance policies, especially Condition Monitoring (CM) or predictive maintenance, and the size of the reserve fleet. The paper deals with exogenous economic variables, specifically the influence of the cost of money, the inflation and real discount rates rate and the cost of fuel. Both variables fluctuate over time. The paper proposes analytical models for determining the influence of those variables on the withdrawal time and the size of the reserve fleet. It then comprehensively summarizes the variables in a global model, showing its relevance to the dimensioning of the reserve fleet and the withdrawal time.
\end{abstract}

Keyword: life cycle cost (LCC), reserve fleet, maintenance, econometric models, economic life, lifespan.

\section{Introduction}

In the passenger transport sector, the determination of the optimum time for bus replacement has an effect on both the efficient use of assets and the global costs of the company.

A company needs to know the right time to replace a bus to reduce costs, guarantee the quality of service, and ensure customer satisfaction. Accordingly, the objective of this paper is to define a methodology to determine the best time to replace a bus.

The paper evaluates the influence of financial costs, specifically, the value or cost of money. To reach this goal, it considers the inflation and real discount rates rate and the price of fuel, two costs to be expected to change significantly over time. It presents models of analysis for determining the influence of these variables on the time of bus withdrawal and on the size of the reserve fleet.

The value of money is directly linked to time: the later an asset is withdrawn from use, the greater the action of external agents or the influence of macroeconomic factors in relation to purchasing power. The inflation rate in any capitalist economic system is a decisive factor in the relationship between money and time: a certain amount of money in a certain month of a certain year does not have the same value in the same month of the following year. In addition, the price of fuel is variable and conditioned by various external factors worldwide. This obviously has an effect on transportation costs.

A reserve fleet is defined as the number of vehicles ready to perform the service for which they have been designed, that is, not immobilized by breakdown or in planned maintenance, in order to maximize the availability of the operating fleet. For the companies of the transport sector, the efficient use of physical assets is linked to a well-structured policy of evaluation and fleet replacement. In national and international road transport companies, there is a wide range of suggested ratios for reserve fleets. However, the recommended size of a fleet reserve specified by the US Federal Transit Administration (FTA) in FTA Circular C 9030.1A (1987) Appendix A is 20\% (Simões 2011).

This paper presents an approach about the influence of the cost of money - particularly with regard to the infla-

${ }^{*}$ Corresponding author. E-mail: hugrap@gmail.com 
tion and real discount rates rate and the costs associated with fuel. It suggests models of analysis for determining the influence of these variables on the withdrawal time and the size of the reserve fleet. The paper also provides a comprehensive summary of the preceding variables through a global model, demonstrating its relevance to the analysis of dimensioning the reserve fleet and determining the withdrawal time.

Following the contributions previously published by the authors, this paper presents some additional contributions, concerning the maintenance politics, namely the Condition Monitoring (CM) with prediction to the dimensioning of the reserve fleet. This paper emphasises the influence of exogenous cost variables to those models, specifically fuel price, inflation and real discount rates, to the time of the withdrawal and the dimensioning of the reserve fleet.

The paper is structured as follows:

- chapter 1 describes the current state-of-the-art analysis;

- chapter 2 synthesizes some approaches;

- chapter 3 describes the influence of inflation rate variables on withdrawal time;

- chapter 4 discusses the influence of fuel cost variables on withdrawal time;

- chapter 5 discusses a condition based maintenance versus reserve fleet;

- chapter 6 presents a global discussion of the models and an integrative approach;

- conclusions and future developments are presented.

\section{State-of-the-art analysis}

The concept of CM was introduced in the late 20th century, around 1970-1980. Briefly stated, CM represented a new approach to preventive maintenance based on knowledge of the health of equipment as determined by a CM system (Cabral 2006). The maintenance of a passenger bus is a strategic activity to maximize the asset's life cycle. It involves a combination of management, technical and economic actions to achieve high availability at reasonable costs (Aoudia et al. 2008; Assis 2014; Assis, Julião 2009; Bescherer 2005; Lindholm, Suomala 2005; Korpi, Ala-Risku 2008) and it frequently relies on CM.

The cost of the life cycle of an asset is the sum of all capital spent in support of that asset from design and manufacturing, through operation until the end of its life (Assis 2014). The Life Cycle Cost (LCC) can be significantly higher than the value of the initial investment and, in many cases, is set in the design phase (Assis, Julião 2009).

The analysis of the cost of the life cycle is a prediction of the future. Several methods can be used for cost estimates, as, for example, Activity-Based Costing (ABC) (Durairaj et al. 2002; Emblemsvag 2001). Certain standards such as those specified in ASTM E917-17; PAS 551:2008; PAS 55-2:2008 - support the cost analysis of the life cycle. The rules on asset management specified in
PAS 55-1:2008, PAS 55-2:2008, i.e. ISO 55000:2014, ISO 55001:2014, ISO 55002:2014 - are good guidelines for asset management and can be applied in any sector.

Although the above points are well-known, there is a lack of systematic study on the area. There is a need to apply and create new equipment management models that can bring added value to companies, allowing them to improve their productivity and quality of service, while taking into account environmental sustainability, including quality management standards, environment, safety, maintenance and energy (Farinha 2011). Many companies keep equipment in operation, even when their operation is no longer economically viable, simply because they do not consider their economic cycle (Farinha 2011). This has exogenous implications in several areas, including the size of the reserve fleet.

According to Sullivan et al. (2002), traditional production systems are built on the principle of scale economy. The authors illustrate an equipment replacement problem in the context of lean thinking.

Rogers and Hartman (2005) refer to technological change as a motivator for equipment replacement and that is commonly assumed that technology is continually developing according to a well-defined function. Hritonenko and Yatsenko (2007) combine discrete and continuous models in time to show that the replacement time for equipment is less when the technology is more advanced.

According to Assaf Neto (2014), "the evaluation of an asset is established by the cash flows expected from future benefits referred to the present value by a discount rate that reflects the risk of the decision". Consequently, methods considering the value of money over time are the most suitable. In the view of Casarotto Filho and Kopittke (2010), the method of annual cost uniform equivalent is suitable for the analysis of operational activities of a company with investments that can be repeated. Furthermore, the standardization of investment based on annual equivalent values facilitates the analysis required for decisionmaking. By using this method, it is possible to determine which year has the lowest equivalent annual cost. This, in turn, indicates the best technical replacement period (Casarotto Filho, Kopittke 2010). The calculation of the equivalent annual cost is based on the capital recovery factor. Using this, it is possible to compare two or more investment opportunities and to determine the best time for equipment replacement, taking into account such information as: (1) value of the investment or acquisition, (2) resale value or residual value at the end of each year, (3) operating costs, (4) the cost of capital or the attractive minimum rate (Vey, Rosa 2004).

To determine the economic life of equipment with the objective of finding the best replacement time, four situations are applicable (Motta, Calôba 2002):

- when the asset is already unsuitable for work;

- when the asset has reached its lifespan;

- when the asset is already obsolete due to technological advances;

- when more efficient methods are more economical. 
Analysis must also consider the following (Farinha 2011):

- availability of new technology;

- compliance with safety standards or other mandatory requirements;

- availability of spare parts;

- obsolescence that may limit its use.

When the equipment enters the final phase of its economic life cycle, it is important to have calculation methods able to determine the appropriate time to withdraw it from use. Several variables are important in such calculations: (1) purchase price, (2) withdrawal value, (3) operating costs, (4) maintenance costs, (5) inflation rate, (6) real discount rate. The values of most of variables are available in the asset's history, except for the withdrawal value. In this case, it is necessary to know the market value for each particular equipment. Unfortunately, this may prove to be difficult for many assets. In such cases, several types of devaluation can be simulated (Oliveira 1982):

- linear method of depreciation - the decline in equipment value is constant over the years;

- sum of digits method - the annual depreciation is not linear;

- exponential method - the annual depreciation decreases over the life of the equipment.

Another common method is to calculate the economic lifespan that ends when the maintenance costs exceed the cost of maintenance plus the capital amortization of a new equivalent equipment. According to Farinha (2011) there are several methods to determine the economic cycle for equipment replacement. The most common are:

- Method of Uniform Annual Income (MUAI);

- Method of Minimizing the Total Average Cost (MMTAC);

- Method of Minimizing the Total Average Cost - Reduced to Present Value (MMTAC-RPV).

Feldens et al. (2010) illustrate the efficient use of physical assets as one of the main objectives of urban passenger transport companies. In the road transport sector, the efficient use of assets is linked to a well-structured policy of fleet evaluation and replacement. Some cases of fleet replacement applied to urban buses are reported in Keles and Hartman (2004), Khasnabis et al. (2002), Jin and Kite-Powell (2000), Scarf and Bouamra (1999), Leung and Cheng (2000), Beichelt (2001), Zohrul Kabir (1996), Wijaya et al. (2012), Raposo et al. (2014).

Campos et al. (2010) present a proposal for a generic model of a stochastic process based on neural networks. The proposed neural stochastic process can be applied to problems involving phenomena showing stochastic behaviour with periodic characteristics. Through neural network models, the behaviour of the historical series of phenomena is modelled without requiring a priori information about the series, by generating synthetic time series also adaptable to time series. Some cases of use of neural networks and stochastic models are reported in Campos et al. (2010), Amaya et al. (2007), Figueiredo (2009), Zhao (2009), Luna et al. (2006), Müller (2007),
Reis et al. (2010), Araujo and Bezerra (2004), Huang and Yao (2008), Vujanović et al. 2012, Gurney (1997).

Other tools may contribute to the development of a new model for optimization of bus replacement, such as fuzzy logic and support vector machine (Tsoukalas et al. 1997; Yager, Zadeh 1992; Campello et al. 2001; Couellan et al. 2015; Chen et al. 2015; Pooyan et al. 2015).

For predictive maintenance, more specifically oil analysis, several mathematical models can be used (Cabral 2006; Farinha 2011; Makridakis et al. 1998; André 2008). In the study of the influence of a $\mathrm{CM}$ or predictive maintenance policy applied to a reserve fleet, it is important to use the appropriate key performance indicators (KPI's) (Cabrita, Cardoso 2015). Here, the NP EN 15341:2009 - "Maintenance - Maintenance Key Performance Indicators" - is a very important standard.

\section{Synthesis of some approaches}

\subsection{Econometric models}

This section summarizes work on equipment replacement models relevant to this paper (Farinha 2011; Raposo et al. 2014). According to (Farinha 2011), equipment can be replaced by several reasons. From a financial point of view, two common criterions are (1) the equipment economic cycle and (2) the lifespan, as discussed in the previous section.

To analyse equipment replacement, two variables should be taken into account:

- real discount rate $i$;

- inflation rate $\theta$.

These rates are related by the following equation:

$$
i_{A}=i+\theta+i \cdot \theta,
$$

where: $i_{A}$ - apparent rate.

The apparent rate is an auxiliary variable that conjugates the real discount and the inflation rates in order to help calculating the Net Present Value (NPV).

According to (Farinha 2011) there are various methods for determining the economic cycle. One of these, the MUAI, makes use of the following data: (1) equipment acquisition cost, (2) withdrawal values (calculated in accordance with the methods above), (3) maintenance and operation costs over time, (4) apparent rate.

The market equipment value suffer depreciation along time. However, for many-used equipment it is not possible to know their market value. When this value is unknown, it is necessary to simulate the equipment depreciation. The equipment under study in this paper are buses for which this situation happens. To solve this problem, this paper uses the exponential method to calculate the withdrawal value of a bus. This method was chosen because it seems more adequate than the linear one, as happens with other types of vehicles. The formula that calculates the annual depreciation cost along the equipment life is expressed by:

$$
d_{l}=V C_{l-1} \cdot\left(1-\sqrt[N]{\frac{V C_{N}}{C A}}\right)
$$




$$
V_{n}=V C_{l-1}-d_{l},
$$

where: $d_{l}$ - annual depreciation quota; $C A$ - cost of acquisition; $N$ - Time of life corresponding to $V C_{N} ; V C_{N}-$ residual value of the equipment at the end of $N$ periods of time; $l=1,2,3, \ldots, N ; V_{n}$ - equipment value in period $n=1,2,3, \ldots, N$.

The NPV per year $n\left(N P V_{n}\right)$ is expressed as:

$$
N P V_{n}=C A+\sum_{j=0}^{n} \frac{C M_{j}+C O_{j}}{\left(1+i_{A}\right)^{j}}-\frac{V_{n}}{\left(1+i_{A}\right)^{j}},
$$

where: $C N_{j}$ - cost of maintenance per year $j=1,2,3, \ldots, n$; $\mathrm{CO}_{j}$ - cost of operation per year $j=1,2,3, \ldots, n$.

The Uniform Annual Income $\left(U A I_{n}\right)$ is written as:

$$
\begin{aligned}
& U A I_{n}=\frac{i_{A} \cdot\left(1+i_{A}\right)^{j}}{\left(1+i_{A}\right)^{j}-1} \times \\
& \left(C A+\sum_{j=0}^{n} \frac{C M_{j}+C O_{j}}{\left(1+i_{A}\right)^{j}}-\frac{V_{n}}{\left(1+i_{A}\right)^{j}}\right) ; \\
& U A I_{n}=\frac{i_{A} \cdot\left(1+i_{A}\right)^{j}}{\left(1+i_{A}\right)^{j}-1} \cdot N P V_{n} .
\end{aligned}
$$

The UAI indicates the period [years], when a bus ought to be replaced. This value is equivalent to the minimum annual cost of the bus.
To apply the models, we consider variables related to direct operating costs and maintenance costs, as well as the relevant economic indicators, such as inflation and interest rates.

Initially, we performed a survey of the operating data for LCC from a bus fleet belonging to a medium-sized public urban transport company.

The fleet bus company has a total of 115 diesel buses, operating in 84 lines, in a total of $556 \mathrm{~km}$ length of road network, carrying annually about 14 million passengers.

The buses were distributed in homogeneous groups; the buses were $21,18,16,12$, and 11 years old. The values are in Euro [€] being divided by one thousand to facilitate their presentation; for example, $3345482 €$ is represented by $33.45 \mathrm{~K}$.

With the goal to validate the replacement models, we created simulation models based on a bus data. Among the several possible approaches based on the sample, due to limitations of space of the paper, we chose to use the same historical data, of the same bus (bus 115), in a period from 1993 to 2014.

In the first step, taking into account the exponential depreciation method and using the MUAI to determine the economic cycle, we computed the results shown in Table 1 and Figure 1.

\begin{tabular}{|c|c|c|c|c|c|c|c|c|c|c|c|}
\hline \multicolumn{9}{|c|}{ Bus 115} & $V C[€]$ & $\begin{array}{c}N P V \\
{[€ \text { year } n]}\end{array}$ & $\begin{array}{c}U A I \\
€ € \text { year } n]\end{array}$ \\
\hline Year & Year $j$ & $C A[€]$ & $i_{A}[\%]$ & $\left(1+i_{A, j}\right)$ & $C M[€]$ & $\mathrm{CO}[€]$ & $\Sigma_{1}[€]$ & $V P[€]$ & Exp. Meth. & Exp. Meth. & Exp. Meth. \\
\hline 1993 & 0 & $110.66 \mathrm{~K}$ & 8 & & & & & & & & \\
\hline 1994 & 1 & & 8 & 1.08 & $0.98 \mathrm{~K}$ & $11.22 \mathrm{~K}$ & $12.20 \mathrm{~K}$ & $121.94 \mathrm{~K}$ & $87.74 \mathrm{~K}$ & $34.20 \mathrm{~K}$ & $36.99 \mathrm{~K}$ \\
\hline 1995 & 2 & & 8 & 1.08 & $1.02 \mathrm{~K}$ & $10.71 \mathrm{~K}$ & $11.73 \mathrm{~K}$ & $131.97 \mathrm{~K}$ & $69.57 \mathrm{~K}$ & $62.40 \mathrm{~K}$ & $35.07 \mathrm{~K}$ \\
\hline 1996 & 3 & & 8 & 1.08 & $1.12 \mathrm{~K}$ & $10.46 \mathrm{~K}$ & $11.58 \mathrm{~K}$ & $141.12 \mathrm{~K}$ & $55.16 \mathrm{~K}$ & $85.96 \mathrm{~K}$ & $33.45 \mathrm{~K}$ \\
\hline 1997 & 4 & & 8 & 1.08 & $1.27 \mathrm{~K}$ & $10.48 \mathrm{~K}$ & $11.76 \mathrm{~K}$ & $149.71 \mathrm{~K}$ & $43.74 \mathrm{~K}$ & $105.97 \mathrm{~K}$ & $32.11 \mathrm{~K}$ \\
\hline 1998 & 5 & & 8 & 1.08 & $1.49 \mathrm{~K}$ & $10.76 \mathrm{~K}$ & $12.25 \mathrm{~K}$ & $157.99 \mathrm{~K}$ & $34.68 \mathrm{~K}$ & $123.31 \mathrm{~K}$ & $31.01 \mathrm{~K}$ \\
\hline 1999 & 6 & & 8 & 1.08 & $1.77 \mathrm{~K}$ & $11.31 \mathrm{~K}$ & $13.07 \mathrm{~K}$ & $166.15 \mathrm{~K}$ & $27.50 \mathrm{~K}$ & $138.65 \mathrm{~K}$ & $30.14 \mathrm{~K}$ \\
\hline 2000 & 7 & & 8 & 1.08 & $2.10 \mathrm{~K}$ & $12.12 \mathrm{~K}$ & $14.22 \mathrm{~K}$ & $174.37 \mathrm{~K}$ & $21.80 \mathrm{~K}$ & $152.56 \mathrm{~K}$ & $29.46 \mathrm{~K}$ \\
\hline 2001 & 8 & & 8 & 1.08 & $2.50 \mathrm{~K}$ & $13.19 \mathrm{~K}$ & $15.69 \mathrm{~K}$ & $182.74 \mathrm{~K}$ & $17.29 \mathrm{~K}$ & $165.45 \mathrm{~K}$ & $28.97 \mathrm{~K}$ \\
\hline 2002 & 9 & & 8 & 1.08 & $2.95 \mathrm{~K}$ & $14.53 \mathrm{~K}$ & $17.48 \mathrm{~K}$ & $191.37 \mathrm{~K}$ & $13.71 \mathrm{~K}$ & $177.66 \mathrm{~K}$ & $28.63 \mathrm{~K}$ \\
\hline 2003 & 10 & & 8 & 1.08 & $3.64 \mathrm{~K}$ & $15.54 \mathrm{~K}$ & $19.18 \mathrm{~K}$ & $200.13 \mathrm{~K}$ & $10.87 \mathrm{~K}$ & $189.26 \mathrm{~K}$ & $28.41 \mathrm{~K}$ \\
\hline 2004 & 11 & & 8 & 1.08 & $3.91 \mathrm{~K}$ & $18.46 \mathrm{~K}$ & $22.37 \mathrm{~K}$ & $209.57 \mathrm{~K}$ & $8.62 \mathrm{~K}$ & $200.95 \mathrm{~K}$ & $28.37 \mathrm{~K}$ \\
\hline 2005 & 12 & & 8 & 1.08 & $5.97 \mathrm{~K}$ & $20.75 \mathrm{~K}$ & $26.72 \mathrm{~K}$ & $219.99 \mathrm{~K}$ & $6.83 \mathrm{~K}$ & $213.16 \mathrm{~K}$ & $28.52 \mathrm{~K}$ \\
\hline 2006 & 13 & & 8 & 1.08 & $5.13 \mathrm{~K}$ & $22.01 \mathrm{~K}$ & $27.15 \mathrm{~K}$ & $229.78 \mathrm{~K}$ & $5.42 \mathrm{~K}$ & $224.36 \mathrm{~K}$ & $28.64 \mathrm{~K}$ \\
\hline 2007 & 14 & & 8 & 1.08 & $5.40 \mathrm{~K}$ & $21.73 \mathrm{~K}$ & $27.13 \mathrm{~K}$ & $238.83 \mathrm{~K}$ & $4.30 \mathrm{~K}$ & $234.53 \mathrm{~K}$ & $28.71 \mathrm{~K}$ \\
\hline 2008 & 15 & & 8 & 1.08 & $6.06 \mathrm{~K}$ & $26.30 \mathrm{~K}$ & $32.37 \mathrm{~K}$ & $248.81 \mathrm{~K}$ & $3.41 \mathrm{~K}$ & $245.40 \mathrm{~K}$ & $28.95 \mathrm{~K}$ \\
\hline 2009 & 16 & & 8 & 1.08 & $7.05 \mathrm{~K}$ & $17.92 \mathrm{~K}$ & $24.97 \mathrm{~K}$ & $255.93 \mathrm{~K}$ & $2.70 \mathrm{~K}$ & $253.22 \mathrm{~K}$ & $28.90 \mathrm{~K}$ \\
\hline 2010 & 17 & & 8 & 1.08 & $10.06 \mathrm{~K}$ & $17.99 \mathrm{~K}$ & $28.05 \mathrm{~K}$ & $263.32 \mathrm{~K}$ & $2.14 \mathrm{~K}$ & $261.18 \mathrm{~K}$ & $28.94 \mathrm{~K}$ \\
\hline 2011 & 18 & & 8 & 1.08 & $8.61 \mathrm{~K}$ & $21.46 \mathrm{~K}$ & $30.07 \mathrm{~K}$ & $270.64 \mathrm{~K}$ & $1.70 \mathrm{~K}$ & $268.95 \mathrm{~K}$ & $29.02 \mathrm{~K}$ \\
\hline 2012 & 19 & & 8 & 1.08 & $6.38 \mathrm{~K}$ & $27.52 \mathrm{~K}$ & $33.90 \mathrm{~K}$ & $278.28 \mathrm{~K}$ & $1.35 \mathrm{~K}$ & $276.93 \mathrm{~K}$ & $29.17 \mathrm{~K}$ \\
\hline 2013 & 20 & & 8 & 1.08 & $8.72 \mathrm{~K}$ & $25.96 \mathrm{~K}$ & $34.68 \mathrm{~K}$ & $285.50 \mathrm{~K}$ & $1.07 \mathrm{~K}$ & $284.44 \mathrm{~K}$ & $29.32 \mathrm{~K}$ \\
\hline 2014 & 21 & & 8 & 1.08 & $9.36 \mathrm{~K}$ & $26.83 \mathrm{~K}$ & $36.19 \mathrm{~K}$ & $292.47 \mathrm{~K}$ & $0.85 \mathrm{~K}$ & $291.63 \mathrm{~K}$ & $29.47 \mathrm{~K}$ \\
\hline
\end{tabular}

In order to support the results inside the Table 1 and Figure 1, the values that were calculated for the first two periods are shown below:

Table 1. UAI (bus 115) 


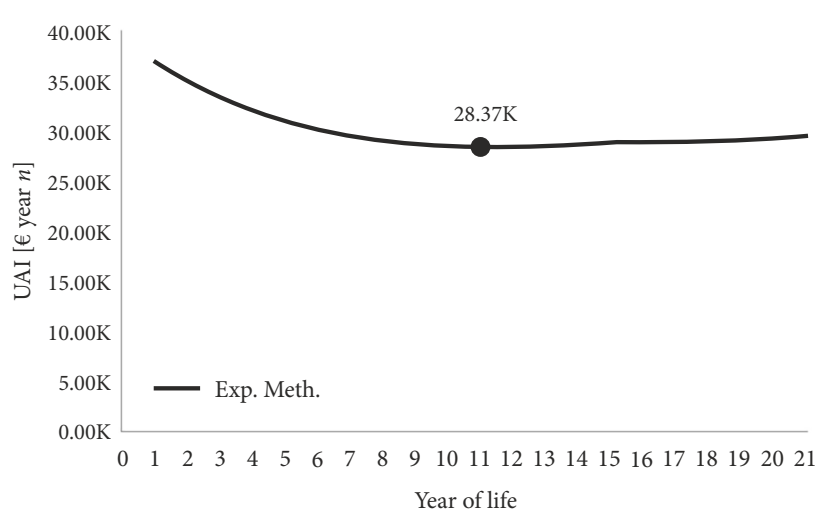

Figure 1. UAI (bus 115)

$$
\begin{aligned}
& N P V_{1}=\left(\frac{110.66}{(1+0.08)^{0}}+\frac{0.98+11.22}{(1+0.08)^{1}}\right)- \\
& \frac{94.90}{(1+0.08)^{1}}=34.20 € ; \\
& U A I_{1}=\frac{0.08 \cdot(1+0.08)^{1}}{(1+0.08)^{1}-1} \cdot 34.20=36.99 € ; \\
& N P V_{2}=\left(\frac{110.66}{(1+0.08)^{0}}+\frac{0.98+11.22}{(1+0.08)^{1}}+\frac{1.02+10.71}{(1+0.08)^{2}}\right)- \\
& \frac{81.39}{(1+0.08)^{2}}=62.40 € ; \\
& U A I_{2}=\frac{0.08 \cdot(1+0.08)^{2}}{(1+0.08)^{2}-1} \cdot 62.40=35.07 € .
\end{aligned}
$$

As the Table 1 and Figure 1 show, there is a clear replacement point in the 11th year. The value of the UAI is $28.37 \mathrm{~K}$. It should be noted that these calculations use a constant apparent rate of $8 \%$.

Another method to determine the economic cycle of equipment replacement is the Method of Minimization of Total Average Cost (MMTAC). This method allows to determine the lowest average cost of bus ownership that corresponds to the optimal replacement time. The capital cost and the inflation rate are not considered. The calculation procedure is as follows:

$$
\begin{aligned}
& C_{n}^{\prime}=\frac{\sum_{j=0}^{n} C M_{j}+C O_{j}}{n} ; \\
& C_{n}^{\prime \prime}=\frac{C A-V_{n}}{n} ; \\
& C_{n(M M T A C)}=C_{n}^{\prime}+C_{n}^{\prime \prime}=\frac{\sum_{j=0}^{n} C M_{j}+C O_{j}}{n}+\frac{C A-V_{n}}{n},
\end{aligned}
$$

where: $n$ - number of years, $n \in\{1,2,3, \ldots, N\} ; C_{n}^{\prime}$ - auxiliary variable; $C_{n}^{\prime \prime}$ - auxiliary variable; $C_{n(M M T A C)}-$ method of minimization total average cost.

Bus 115 is again presented as example, taking into account the method of exponential depreciation using the MMTAC to determine the vehicle's economic cycle (Table 2 and Figure 2).

In order to support the results inside the Table 2 and Figure 2, the values that were calculated for the first two periods are shown below:

$$
\begin{aligned}
& C_{1(\text { MMTAC })}=\frac{0.98+11.22}{1}+\frac{110.66-94.90}{1}=27.96 € ; \\
& C_{2(\text { MMTAC })}=\frac{0.98+11.22}{2}+\frac{1.02+10.71}{2}+ \\
& \frac{110.66-81.39}{2}=26.60 € .
\end{aligned}
$$

The Table 2 and Figure 2 show an evident replacement point in the 9 th year of life. The minimum bus ownership cost is $22.54 \mathrm{~K}$.

Finally, we use the MMTAC-RPV. The calculation procedure is the same as the one above but this one considers capital costs and inflation rate. The various maintenance and withdrawal values over time are reduced to the present value, using the following procedure:

$$
\begin{aligned}
& C_{n}^{\prime}=\frac{1}{n} \cdot \sum_{j=1}^{n} \frac{C M_{j}+C O_{j}}{\left(1+i_{A}\right)^{j}} ; \\
& C_{n}^{\prime \prime}=\frac{C A-\frac{V_{n}}{\left(1+i_{A}\right)^{j}}}{n} ; \\
& C_{n(M M T A C-R P V)}=C_{n}^{\prime}+C_{n}^{\prime \prime}= \\
& \frac{1}{n} \cdot \sum_{j=1}^{n} \frac{C M_{j}+C O_{j}}{\left(1+i_{A}\right)^{j}}+\frac{C A-\frac{V_{n}}{\left(1+i_{A}\right)^{j}}}{n},
\end{aligned}
$$

where: $\mathrm{C}_{n(M M T A C-R P V)}$ - method of minimization total average cost - reduced to present value.

Finally, Table 3 and Figure 3 take into account the exponential depreciation method using the MMTAC-RPV to determine the economic cycle of bus 115 .

In order to support the results inside the Table 3 and Figure 3, the values that were calculated for the first two periods are shown below:

$$
\begin{aligned}
& C_{1(M M T A C-R P V)}=\frac{1}{1} \times \\
& \left(\frac{0.98+11.22}{(1+0.08)^{1}}+\frac{110.66-\frac{94.90}{(1+0.08)^{1}}}{1}\right)=34.09 € ; \\
& C_{2(M M T A C-R P V)}=\frac{1}{2} \times \\
& \left(\frac{0.98+11.22}{(1+0.08)^{1}+\frac{1.02+10.71}{(1+0.08)^{2}}}\right)+ \\
& \frac{110.66-\frac{81.39}{(1+0.08)^{2}}}{2}=31.12 € .
\end{aligned}
$$


Table 2. Minimization of total average cost (bus 115)

\begin{tabular}{|c|c|c|c|c|c|c|c|}
\hline \multicolumn{3}{|c|}{ Bus 115} & \multicolumn{3}{|c|}{$C^{\prime}[€]$} & \multirow{2}{*}{$\frac{C^{\prime \prime}[€]}{\text { Exp. Meth. }}$} & \multirow{2}{*}{$\frac{C_{n(M M T A C)}[€ \text { year } n]}{\text { Exp. Meth. }}$} \\
\hline Year & Year $j$ & $C A[€]$ & $C M[€]$ & $C O[€]$ & $\Sigma_{1}[€]$ & & \\
\hline 1993 & 0 & $110.66 \mathrm{~K}$ & & & & & \\
\hline 1994 & 1 & & $0.98 \mathrm{~K}$ & $11.22 \mathrm{~K}$ & $12.20 \mathrm{~K}$ & $15.76 \mathrm{~K}$ & $27.96 \mathrm{~K}$ \\
\hline 1995 & 2 & & $1.02 \mathrm{~K}$ & $10.71 \mathrm{~K}$ & $11.97 \mathrm{~K}$ & $14.63 \mathrm{~K}$ & $26.60 \mathrm{~K}$ \\
\hline 1996 & 3 & & $1.12 \mathrm{~K}$ & $10.46 \mathrm{~K}$ & $11.84 \mathrm{~K}$ & $13.62 \mathrm{~K}$ & $25.46 \mathrm{~K}$ \\
\hline 1997 & 4 & & $1.27 \mathrm{~K}$ & $10.48 \mathrm{~K}$ & $11.82 \mathrm{~K}$ & $12.70 \mathrm{~K}$ & $24.52 \mathrm{~K}$ \\
\hline 1998 & 5 & & $1.49 \mathrm{~K}$ & $10.76 \mathrm{~K}$ & $11.90 \mathrm{~K}$ & $11.86 \mathrm{~K}$ & $23.77 \mathrm{~K}$ \\
\hline 1999 & 6 & & $1.77 \mathrm{~K}$ & $11.31 \mathrm{~K}$ & $12.10 \mathrm{~K}$ & $11.11 \mathrm{~K}$ & $23.20 \mathrm{~K}$ \\
\hline 2000 & 7 & & $2.10 \mathrm{~K}$ & $12.12 \mathrm{~K}$ & $12.40 \mathrm{~K}$ & $10.41 \mathrm{~K}$ & $22.82 \mathrm{~K}$ \\
\hline 2001 & 8 & & $2.50 \mathrm{~K}$ & $13.19 \mathrm{~K}$ & $12.81 \mathrm{~K}$ & $9.78 \mathrm{~K}$ & $22.60 \mathrm{~K}$ \\
\hline 2002 & 9 & & $2.95 \mathrm{~K}$ & $14.53 \mathrm{~K}$ & $13.33 \mathrm{~K}$ & $9.21 \mathrm{~K}$ & $22.54 \mathrm{~K}$ \\
\hline 2003 & 10 & & $3.64 \mathrm{~K}$ & $15.54 \mathrm{~K}$ & $13.92 \mathrm{~K}$ & $8.68 \mathrm{~K}$ & $22.60 \mathrm{~K}$ \\
\hline 2004 & 11 & & $3.91 \mathrm{~K}$ & $18.46 \mathrm{~K}$ & $14.69 \mathrm{~K}$ & $8.20 \mathrm{~K}$ & $22.89 \mathrm{~K}$ \\
\hline 2005 & 12 & & $5.97 \mathrm{~K}$ & $20.75 \mathrm{~K}$ & $15.69 \mathrm{~K}$ & $7.76 \mathrm{~K}$ & $23.45 \mathrm{~K}$ \\
\hline 2006 & 13 & & $5.13 \mathrm{~K}$ & $22.01 \mathrm{~K}$ & $16.57 \mathrm{~K}$ & $7.36 \mathrm{~K}$ & $23.93 \mathrm{~K}$ \\
\hline 2007 & 14 & & $5.40 \mathrm{~K}$ & $21.73 \mathrm{~K}$ & $17.32 \mathrm{~K}$ & $6.98 \mathrm{~K}$ & $24.31 \mathrm{~K}$ \\
\hline 2008 & 15 & & $6.06 \mathrm{~K}$ & $26.30 \mathrm{~K}$ & $18.33 \mathrm{~K}$ & $6.64 \mathrm{~K}$ & $24.97 \mathrm{~K}$ \\
\hline 2009 & 16 & & $7.05 \mathrm{~K}$ & $17.92 \mathrm{~K}$ & $18.74 \mathrm{~K}$ & $6.32 \mathrm{~K}$ & $25.07 \mathrm{~K}$ \\
\hline 2010 & 17 & & $10.06 \mathrm{~K}$ & $17.99 \mathrm{~K}$ & $19.29 \mathrm{~K}$ & $6.03 \mathrm{~K}$ & $25.32 \mathrm{~K}$ \\
\hline 2011 & 18 & & $8.61 \mathrm{~K}$ & $21.46 \mathrm{~K}$ & $19.89 \mathrm{~K}$ & $5.76 \mathrm{~K}$ & $25.65 \mathrm{~K}$ \\
\hline 2012 & 19 & & $6.38 \mathrm{~K}$ & $27.52 \mathrm{~K}$ & $20.63 \mathrm{~K}$ & $5.51 \mathrm{~K}$ & $26.14 \mathrm{~K}$ \\
\hline 2013 & 20 & & $8.72 \mathrm{~K}$ & $25.96 \mathrm{~K}$ & $21.33 \mathrm{~K}$ & $5.28 \mathrm{~K}$ & $26.60 \mathrm{~K}$ \\
\hline 2014 & 21 & & $9.36 \mathrm{~K}$ & $26.83 \mathrm{~K}$ & $22.04 \mathrm{~K}$ & $5.06 \mathrm{~K}$ & $27.10 \mathrm{~K}$ \\
\hline
\end{tabular}

Table 3. MMTAC-RPV (bus 115)

\begin{tabular}{|c|c|c|c|c|c|c|c|c|c|c|}
\hline \multicolumn{5}{|c|}{ Bus 115} & \multicolumn{4}{|c|}{$C^{\prime}[€]$} & \multirow{2}{*}{$\frac{C^{\prime \prime}[€]}{\text { Exp. Meth. }}$} & \multirow{2}{*}{$\frac{C_{n(M M T A C-R P V)}[€ \text { year } n]}{\text { Exp. Meth. }}$} \\
\hline Year & Year $j$ & $C A[€]$ & $i_{A}[\%]$ & $\left(1+i_{A, j}\right)$ & $C M[€]$ & $\mathrm{CO}[€]$ & $\Sigma_{1}[€]$ & $\Sigma_{2}[€]$ & & \\
\hline 1993 & 0 & $110.66 \mathrm{~K}$ & 8 & & & & & & & \\
\hline 1994 & 1 & & 8 & 1.08 & $0.98 \mathrm{~K}$ & $11.22 \mathrm{~K}$ & $11.30 \mathrm{~K}$ & $11.30 \mathrm{~K}$ & $22.79 \mathrm{~K}$ & $34.09 \mathrm{~K}$ \\
\hline 1995 & 2 & & 8 & 1.08 & $1.02 \mathrm{~K}$ & $10.71 \mathrm{~K}$ & $10.68 \mathrm{~K}$ & $11.08 \mathrm{~K}$ & $20.44 \mathrm{~K}$ & $31.12 \mathrm{~K}$ \\
\hline 1996 & 3 & & 8 & 1.08 & $1.12 \mathrm{~K}$ & $10.46 \mathrm{~K}$ & $10.18 \mathrm{~K}$ & $10.96 \mathrm{~K}$ & $18.42 \mathrm{~K}$ & $28.60 \mathrm{~K}$ \\
\hline 1997 & 4 & & 8 & 1.08 & $1.27 \mathrm{~K}$ & $10.48 \mathrm{~K}$ & $9.80 \mathrm{~K}$ & $10.94 \mathrm{~K}$ & $16.66 \mathrm{~K}$ & $26.46 \mathrm{~K}$ \\
\hline 1998 & 5 & & 8 & 1.08 & $1.49 \mathrm{~K}$ & $10.76 \mathrm{~K}$ & $9.51 \mathrm{~K}$ & $11.02 \mathrm{~K}$ & $15.14 \mathrm{~K}$ & $24.65 \mathrm{~K}$ \\
\hline 1999 & 6 & & 8 & 1.08 & $1.77 \mathrm{~K}$ & $11.31 \mathrm{~K}$ & $9.29 \mathrm{~K}$ & $11.20 \mathrm{~K}$ & $13.82 \mathrm{~K}$ & $23.11 \mathrm{~K}$ \\
\hline 2000 & 7 & & 8 & 1.08 & $2.10 \mathrm{~K}$ & $12.12 \mathrm{~K}$ & $9.15 \mathrm{~K}$ & $11.48 \mathrm{~K}$ & $12.66 \mathrm{~K}$ & $21.81 \mathrm{~K}$ \\
\hline 2001 & 8 & & 8 & 1.08 & $2.50 \mathrm{~K}$ & $13.19 \mathrm{~K}$ & $9.07 \mathrm{~K}$ & $11.86 \mathrm{~K}$ & $11.65 \mathrm{~K}$ & $20.71 \mathrm{~K}$ \\
\hline 2002 & 9 & & 8 & 1.08 & $2.95 \mathrm{~K}$ & $14.53 \mathrm{~K}$ & $9.03 \mathrm{~K}$ & $12.34 \mathrm{~K}$ & $10.75 \mathrm{~K}$ & $19.78 \mathrm{~K}$ \\
\hline 2003 & 10 & & 8 & 1.08 & $3.64 \mathrm{~K}$ & $15.54 \mathrm{~K}$ & $9.02 \mathrm{~K}$ & $12.89 \mathrm{~K}$ & $9.96 \mathrm{~K}$ & $18.98 \mathrm{~K}$ \\
\hline 2004 & 11 & & 8 & 1.08 & $3.91 \mathrm{~K}$ & $18.46 \mathrm{~K}$ & $9.07 \mathrm{~K}$ & $13.60 \mathrm{~K}$ & $9.26 \mathrm{~K}$ & $18.33 \mathrm{~K}$ \\
\hline 2005 & 12 & & 8 & 1.08 & $5.97 \mathrm{~K}$ & $20.75 \mathrm{~K}$ & $9.20 \mathrm{~K}$ & $14.53 \mathrm{~K}$ & $8.64 \mathrm{~K}$ & $17.84 \mathrm{~K}$ \\
\hline 2006 & 13 & & 8 & 1.08 & $5.13 \mathrm{~K}$ & $22.01 \mathrm{~K}$ & $9.26 \mathrm{~K}$ & $15.34 \mathrm{~K}$ & $8.09 \mathrm{~K}$ & $17.35 \mathrm{~K}$ \\
\hline 2007 & 14 & & 8 & 1.08 & $5.40 \mathrm{~K}$ & $21.73 \mathrm{~K}$ & $9.26 \mathrm{~K}$ & $16.04 \mathrm{~K}$ & $7.59 \mathrm{~K}$ & $16.85 \mathrm{~K}$ \\
\hline 2008 & 15 & & 8 & 1.08 & $6.06 \mathrm{~K}$ & $26.30 \mathrm{~K}$ & $9.32 \mathrm{~K}$ & $16.97 \mathrm{~K}$ & $7.15 \mathrm{~K}$ & $16.46 \mathrm{~K}$ \\
\hline 2009 & 16 & & 8 & 1.08 & $7.05 \mathrm{~K}$ & $17.92 \mathrm{~K}$ & $9.19 \mathrm{~K}$ & $17.35 \mathrm{~K}$ & $6.74 \mathrm{~K}$ & $15.94 \mathrm{~K}$ \\
\hline 2010 & 17 & & 8 & 1.08 & $10.06 \mathrm{~K}$ & $17.99 \mathrm{~K}$ & $9.10 \mathrm{~K}$ & $17.86 \mathrm{~K}$ & $6.38 \mathrm{~K}$ & $15.48 \mathrm{~K}$ \\
\hline 2011 & 18 & & 8 & 1.08 & $8.61 \mathrm{~K}$ & $21.46 \mathrm{~K}$ & $9.01 \mathrm{~K}$ & $18.42 \mathrm{~K}$ & $6.05 \mathrm{~K}$ & $15.06 \mathrm{~K}$ \\
\hline 2012 & 19 & & 8 & 1.08 & $6.38 \mathrm{~K}$ & $27.52 \mathrm{~K}$ & $8.95 \mathrm{~K}$ & $19.10 \mathrm{~K}$ & $5.75 \mathrm{~K}$ & $14.70 \mathrm{~K}$ \\
\hline 2013 & 20 & & 8 & 1.08 & $8.72 \mathrm{~K}$ & $25.96 \mathrm{~K}$ & $8.87 \mathrm{~K}$ & $19.75 \mathrm{~K}$ & $5.48 \mathrm{~K}$ & $14.35 \mathrm{~K}$ \\
\hline 2014 & 21 & & 8 & 1.08 & $9.36 \mathrm{~K}$ & $26.83 \mathrm{~K}$ & $8.79 \mathrm{~K}$ & $20.40 \mathrm{~K}$ & $5.23 \mathrm{~K}$ & $14.02 \mathrm{~K}$ \\
\hline
\end{tabular}




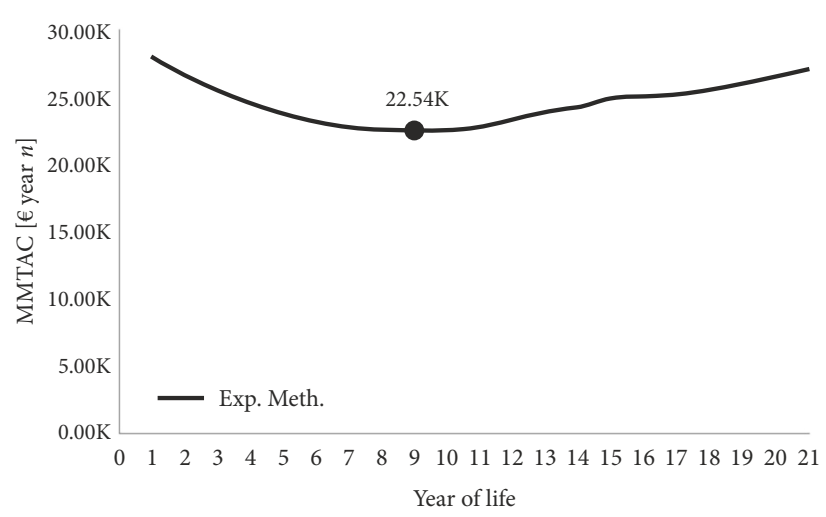

Figure 2. Minimization of total average cost (bus 115)

Neither the table nor the graphic show an evident point of lower average cost of equipment ownership; the average cost of ownership continues to decline and there is no reversal point in the path of the ownership cost within the time interval considered.

To evaluate the efficiency of an investment, one possible measure is the Return On Investment (ROI), which depends on ensuring the maximum availability of the assets at the lowest cost. ROI measures the amount of return on an investment, in percentage, relative to the investment's cost. In the case discussed in this paper, it is used a variable $R O I_{a}$, in absolute value, that corresponds to the following formula:

$$
R O I_{a}=\left(-\frac{C A}{\left(1+i_{A}\right)^{j}}+\frac{P f_{j}}{\left(1+i_{A}\right)^{j}}\right)-\frac{\left(C_{n}^{\prime}+C_{n}^{\prime \prime}\right)}{\left(1+i_{A}\right)^{j}} .
$$

The Tables 4, 5 and Figures 4, 5 shown below illustrate these values for a hypothetic bus.

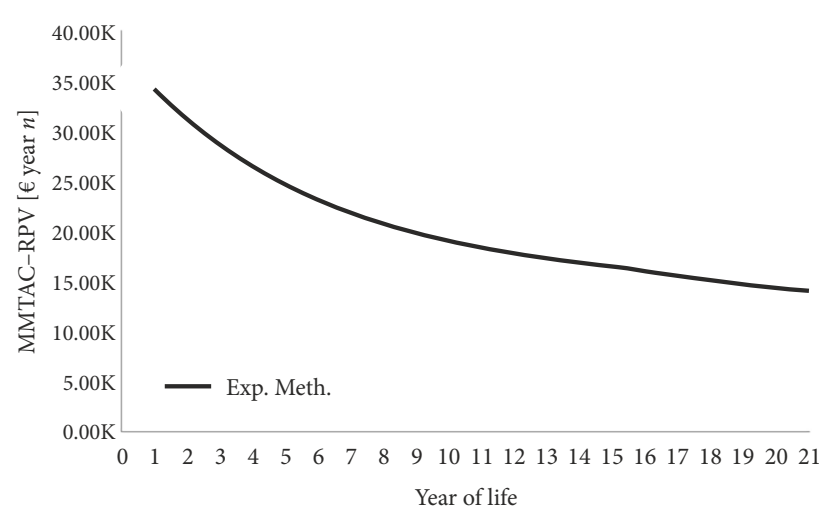

Figure 3. MMTAC-RPV (bus 115)

The last two numerical examples allow to cross the $R O I_{a}$ value with the econometric models used to evaluate the withdrawal time, including the simulation of the past and future values for the several life cycle variables. The past values of the variables were simulated by fixed values and were afterwards corrected by the apparent rate.

\section{Influence of apparent rate}

This section discusses the influence of the inflation and real discount rates on the economic cycle of bus replacement, along the bus life cycle. It uses the same bus data to facilitate comparison. Figures 6 and 7 show charts with inflation and real discount rates, respectively, in Portugal between 1993 and 2014.

Figure 7 illustrates the variation in real discount rate in Portugal in the previous year's range.

Finally, Figure 8 illustrates the evolution of the apparent rate resulting from the two previous rates for the time considered time interval.

Table 4. MMTAC-RPV: $R O I_{a}+\left(C_{n}^{\prime}+C_{n}^{\prime \prime}\right)$

\begin{tabular}{|l|c|c|c|c|c|c|c|}
\hline \multicolumn{1}{|c|}{ Years } & -3 & -2 & -1 & 0 & 1 & 2 & 3 \\
\hline Purchase, $C A$ & & & & $159.52 \mathrm{~K}$ & & & \\
\hline Purchase, $C A(R P V)$ & $253.13 \mathrm{~K}$ & $200.94 \mathrm{~K}$ & $172.28 \mathrm{~K}$ & $159.52 \mathrm{~K}$ & $147.70 \mathrm{~K}$ & $126.63 \mathrm{~K}$ & $100.52 \mathrm{~K}$ \\
\hline Exploration cost, $E C$ & $18.30 \mathrm{~K}$ & $18.30 \mathrm{~K}$ & $18.30 \mathrm{~K}$ & & $18.30 \mathrm{~K}$ & $27.82 \mathrm{~K}$ & $30.72 \mathrm{~K}$ \\
\hline Exploration cost, $E C-10 \%$ incr. & $20.13 \mathrm{~K}$ & $20.13 \mathrm{~K}$ & $20.13 \mathrm{~K}$ & & $20.13 \mathrm{~K}$ & $30.60 \mathrm{~K}$ & $33.79 \mathrm{~K}$ \\
\hline Exploration cost, $E C-R P V$ & $25.36 \mathrm{~K}$ & $23.48 \mathrm{~K}$ & $21.74 \mathrm{~K}$ & & $18.64 \mathrm{~K}$ & $26.24 \mathrm{~K}$ & $26.83 \mathrm{~K}$ \\
\hline$C^{\prime}$ & $8.45 \mathrm{~K}$ & $24.42 \mathrm{~K}$ & $70.57 \mathrm{~K}$ & & $18.64 \mathrm{~K}$ & $22.44 \mathrm{~K}$ & $23.90 \mathrm{~K}$ \\
\hline Cession, $V C_{n}$ & $175.00 \mathrm{~K}$ & $170.00 \mathrm{~K}$ & $165.00 \mathrm{~K}$ & & $135.03 \mathrm{~K}$ & $114.30 \mathrm{~K}$ & $96.75 \mathrm{~K}$ \\
\hline Cession $V C_{n}-R P V$ & $220.45 \mathrm{~K}$ & $198.29 \mathrm{~K}$ & $178.20 \mathrm{~K}$ & & $125.03 \mathrm{~K}$ & $97.99 \mathrm{~K}$ & $76.80 \mathrm{~K}$ \\
\hline$C_{n}^{\prime \prime}$ & $20.31 \mathrm{~K}$ & $19.39 \mathrm{~K}$ & $18.68 \mathrm{~K}$ & $159.52 \mathrm{~K}$ & $34.49 \mathrm{~K}$ & $30.76 \mathrm{~K}$ & $27.57 \mathrm{~K}$ \\
\hline$C_{n}^{\prime}+C_{n}^{\prime \prime}$ & $28.76 \mathrm{~K}$ & $43.80 \mathrm{~K}$ & $89.26 \mathrm{~K}$ & $159.52 \mathrm{~K}$ & $53.13 \mathrm{~K}$ & $53.20 \mathrm{~K}$ & $51.47 \mathrm{~K}$ \\
\hline$E C-R P V$ accumulated & $25.36 \mathrm{~K}$ & $48.84 \mathrm{~K}$ & $70.57 \mathrm{~K}$ & $159.52 \mathrm{~K}$ & $18.64 \mathrm{~K}$ & $44.88 \mathrm{~K}$ & $71.70 \mathrm{~K}$ \\
\hline Profit, $P f$ & & & & & $197.00 \mathrm{~K}$ & $200.00 \mathrm{~K}$ & $210.00 \mathrm{~K}$ \\
\hline$P f-R P V$ & & & & & $182.41 \mathrm{~K}$ & $171.47 \mathrm{~K}$ & $166.70 \mathrm{~K}$ \\
\hline$R O I{ }_{a}+\left(C_{n}^{\prime}+C_{n}^{\prime \prime}\right)-R P V$ & & & & $-159.52 \mathrm{~K}$ & $-30.24 \mathrm{~K}$ & $-29.43 \mathrm{~K}$ & $-11.40 \mathrm{~K}$ \\
\hline
\end{tabular}


Table 5. MMTAC-RPV: $R O I_{a}$ and life with accumulated costs

\begin{tabular}{|l|c|c|c|c|c|c|c|}
\hline \multicolumn{1}{|c|}{ Years } & -3 & -2 & -1 & 0 & 1 & 2 & 3 \\
\hline Purchase, $C A$ & & & & $159.52 \mathrm{~K}$ & & & \\
\hline Purchase, $C A(R P V)$ & $253.13 \mathrm{~K}$ & $200.94 \mathrm{~K}$ & $172.28 \mathrm{~K}$ & $159.52 \mathrm{~K}$ & $147.70 \mathrm{~K}$ & $126.63 \mathrm{~K}$ & $100.52 \mathrm{~K}$ \\
\hline Exploration cost, $E C$ & $18.30 \mathrm{~K}$ & $18.30 \mathrm{~K}$ & $18.30 \mathrm{~K}$ & & $18.30 \mathrm{~K}$ & $27.82 \mathrm{~K}$ & $30.72 \mathrm{~K}$ \\
\hline Exploration cost, $E C-R P V$ & $23.05 \mathrm{~K}$ & $21.34 \mathrm{~K}$ & $19.76 \mathrm{~K}$ & & $16.94 \mathrm{~K}$ & $23.85 \mathrm{~K}$ & $24.39 \mathrm{~K}$ \\
\hline$C^{\prime}$ & $7.68 \mathrm{~K}$ & $22.20 \mathrm{~K}$ & $64.16 \mathrm{~K}$ & & $16.94 \mathrm{~K}$ & $20.40 \mathrm{~K}$ & $21.73 \mathrm{~K}$ \\
\hline Cession, $V C_{n}$ & $175.00 \mathrm{~K}$ & $170.00 \mathrm{~K}$ & $165.00 \mathrm{~K}$ & & $135.03 \mathrm{~K}$ & $114.30 \mathrm{~K}$ & $96.75 \mathrm{~K}$ \\
\hline Cession $V C_{n}-R P V$ & $220.45 \mathrm{~K}$ & $198.29 \mathrm{~K}$ & $178.20 \mathrm{~K}$ & & $125.03 \mathrm{~K}$ & $97.99 \mathrm{~K}$ & $76.80 \mathrm{~K}$ \\
\hline$C_{n}^{\prime \prime}$ & $20.31 \mathrm{~K}$ & $19.39 \mathrm{~K}$ & $18.68 \mathrm{~K}$ & $159.52 \mathrm{~K}$ & $34.49 \mathrm{~K}$ & $30.76 \mathrm{~K}$ & $27.57 \mathrm{~K}$ \\
\hline$C_{n}^{\prime}+C_{n}^{\prime \prime}$ & $28.00 \mathrm{~K}$ & $41.58 \mathrm{~K}$ & $82.84 \mathrm{~K}$ & $159.52 \mathrm{~K}$ & $51.43 \mathrm{~K}$ & $51.16 \mathrm{~K}$ & $49.30 \mathrm{~K}$ \\
\hline$E C-R P V$ accumulated & $23.05 \mathrm{~K}$ & $44.40 \mathrm{~K}$ & $64.16 \mathrm{~K}$ & $159.52 \mathrm{~K}$ & $16.94 \mathrm{~K}$ & $40.80 \mathrm{~K}$ & $65.18 \mathrm{~K}$ \\
\hline Profit, $P f$ & & & & & $100.00 \mathrm{~K}$ & $100.00 \mathrm{~K}$ & $110.00 \mathrm{~K}$ \\
\hline$P f-R P V$ & & & & & $92.59 \mathrm{~K}$ & $85.73 \mathrm{~K}$ & $87.32 \mathrm{~K}$ \\
\hline$R O I_{a}-R P V$ & & & & $-159.52 \mathrm{~K}$ & $-66.92 \mathrm{~K}$ & $18.81 \mathrm{~K}$ & $106.13 \mathrm{~K}$ \\
\hline$E C-R P V$ accumulated & & & & & $16.94 \mathrm{~K}$ & $40.80 \mathrm{~K}$ & $65.18 \mathrm{~K}$ \\
\hline
\end{tabular}

\begin{tabular}{r|r|c|c|c|c|c|c|c|c|c|}
\hline \\
\hline- Years
\end{tabular}

Figure 4. MMTAC-RPV: $R O I_{a}+\left(C_{n}^{\prime}+C_{n}^{\prime \prime}\right)$

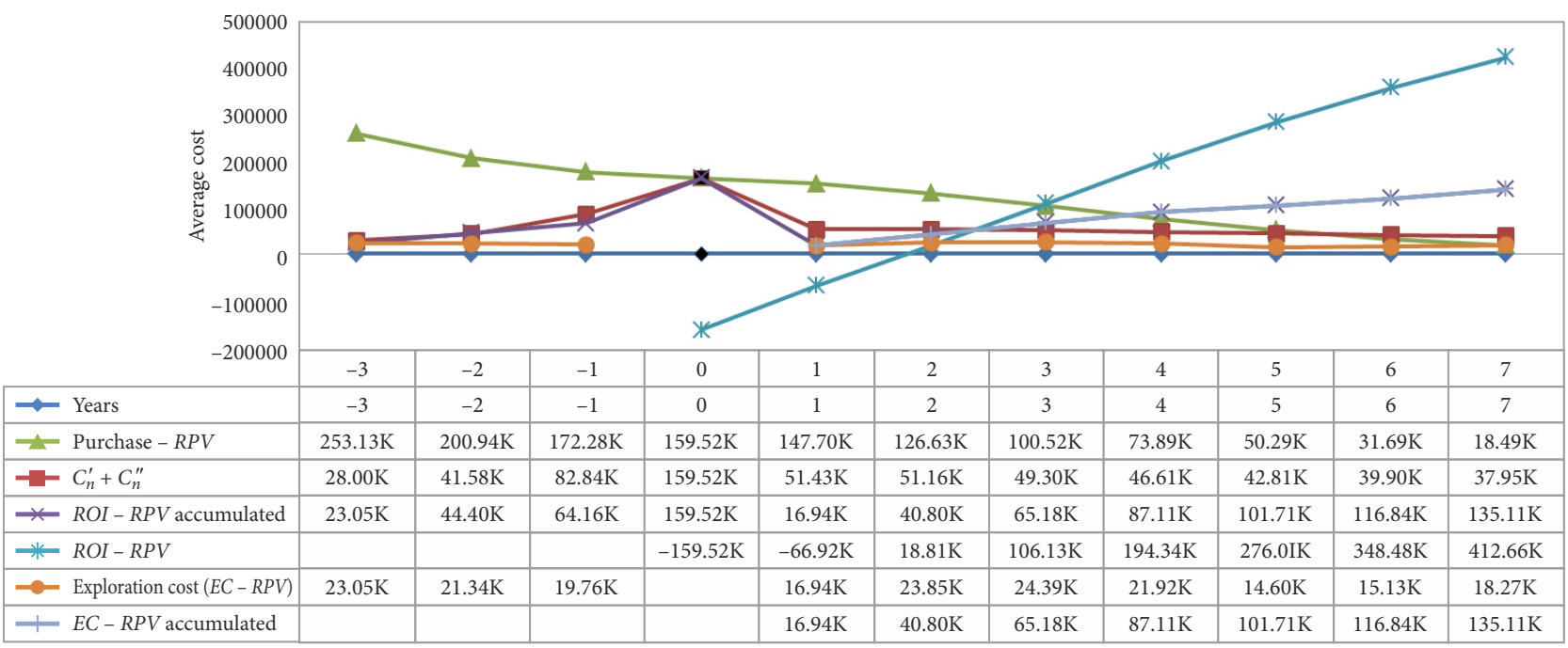

Figure 5. MMTAC-RPV: $R O I_{a}$ and life with accumulated costs 


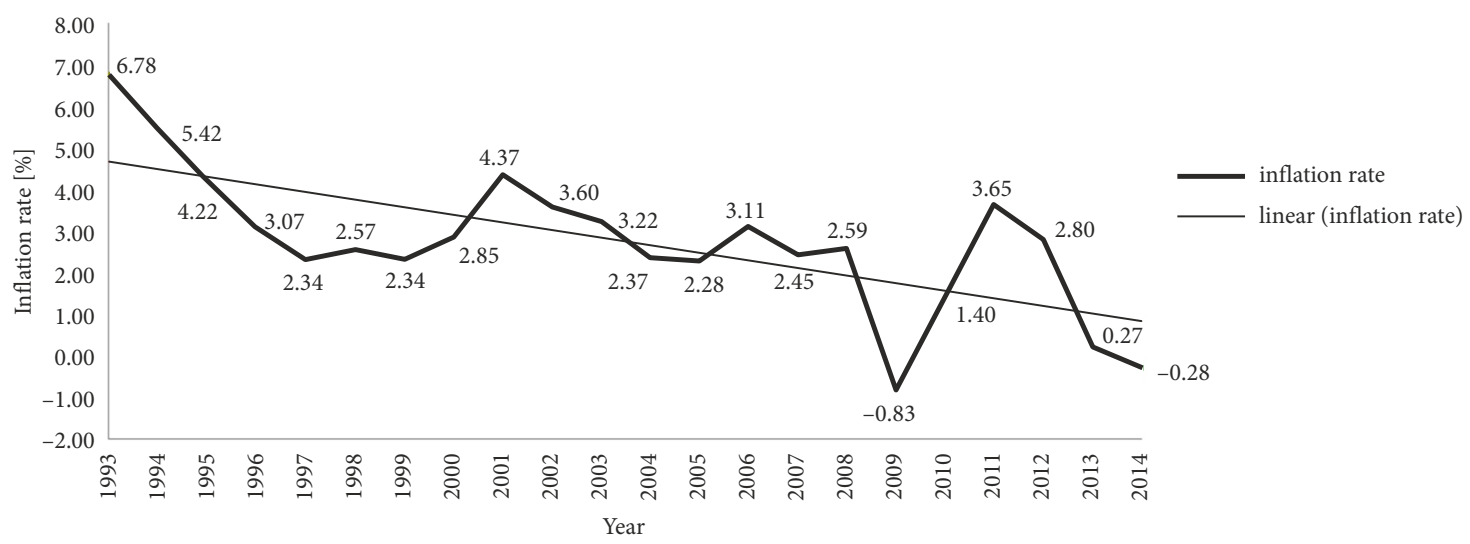

Figure 6. Change in inflation rate between 1993 and 2014

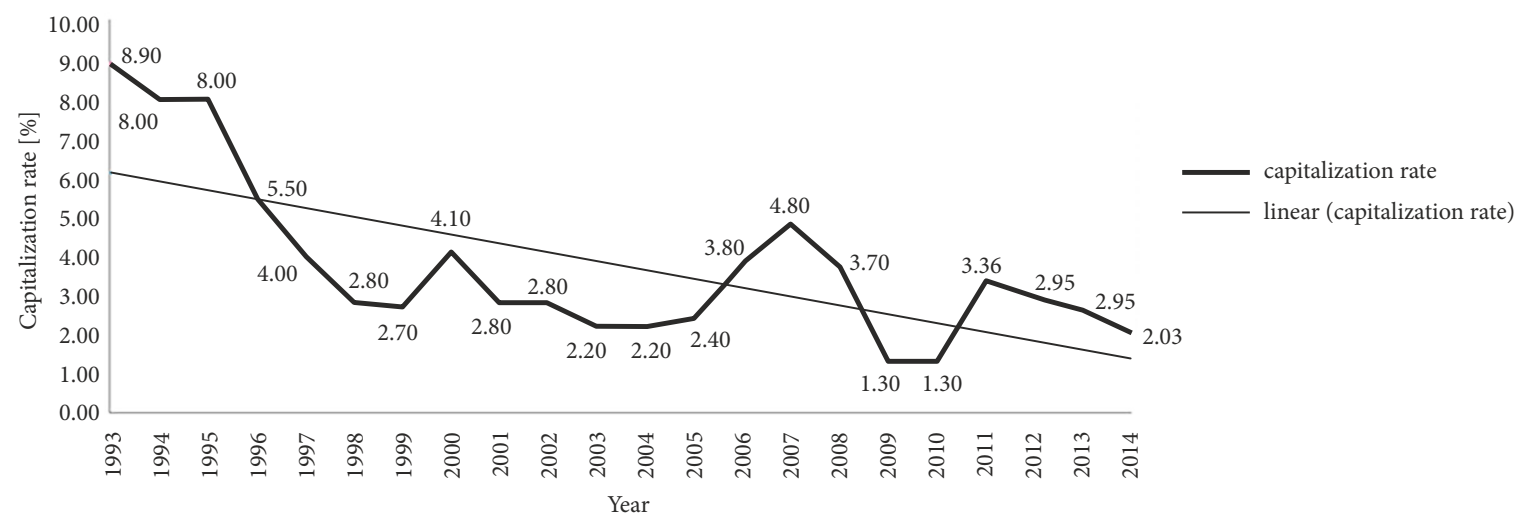

Figure 7. Change in real discount rate between 1993 and 2014

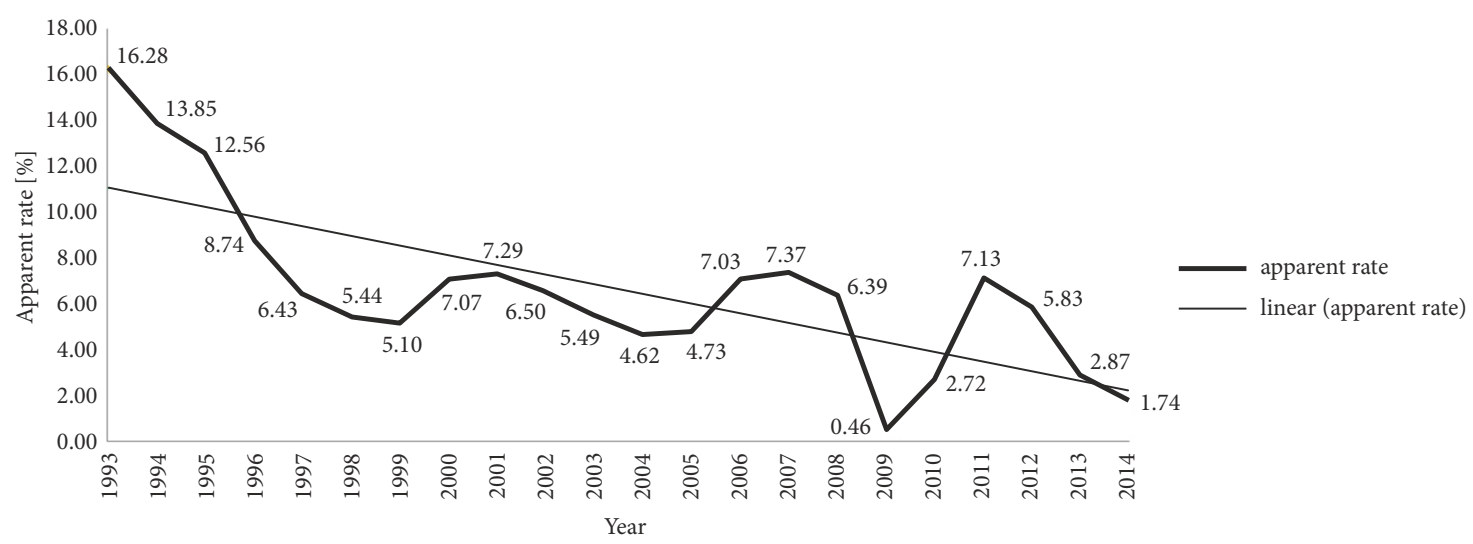

Figure 8. Change in apparent rate between 1993 and 2014

The first consideration is the effect of apparent rate on the UAI, using real data. Table 6 and Figure 9 show these calculations for bus 115 - the same bus used in the previous section.

It can be verified, through the Table 6 and Figure 9, some oscillations of the UAI over the years. In this case, it can be observed a lot of oscillations that cannot be indexed to the apparent rate variation, but a not good quality of the company's maintenance policy, what do not make clear the bus withdrawal time.

Because of the precedent situation, it will be used some theoretical data in order to exemplify the importance of the apparent rate in the withdrawal time, as will be dis- cussed next. Table 7 and Figure 10 show these theoretical calculations.

As the Table 7 and Figure 10 show, the replacement point is located in the 17 th year of life. The UAI is $27.50 \mathrm{~K}$.

As said before, there is big influence in the increase of the apparent rate on the MUAI. The results appear in Table 8 and Figure 11, again for bus 115 .

As the Table 8 and Figure 11 show, the replacement point is in the 12th year of life, so the increase in the inflation rate and or the real discount rate over time increases the apparent rate. The value of the UAI is $31.53 \mathrm{~K}$. In other words, the rise in the apparent rate substantially increases the UAI of the bus. 
Table 6. Actual apparent rate: MUAI (bus 115)

\begin{tabular}{|c|c|c|c|c|c|c|c|c|c|c|c|}
\hline \multicolumn{9}{|c|}{ Bus 115} & \multirow{2}{*}{$\begin{array}{c}V C[€] \\
\text { Exp. Meth. }\end{array}$} & \multirow{2}{*}{$\frac{N P V[€ \text { Year } n]}{\text { Exp. Meth. }}$} & \multirow{2}{*}{$\begin{array}{c}U A I[€ \text { Year } n] \\
\text { Exp. Meth. }\end{array}$} \\
\hline Year & Year $j$ & $C A[€]$ & $i_{A}[\%]$ & $\left(1+i_{A, j}\right)$ & $C M[€]$ & $\mathrm{CO}[€]$ & $\Sigma_{1}[€]$ & $V P[€]$ & & & \\
\hline 1993 & 0 & $110.66 \mathrm{~K}$ & 16 & & & & & & & & \\
\hline 1994 & 1 & & 14 & 1.14 & $1.00 \mathrm{~K}$ & $10.00 \mathrm{~K}$ & $11.00 \mathrm{~K}$ & $120.32 \mathrm{~K}$ & $83.35 \mathrm{~K}$ & $36.97 \mathrm{~K}$ & $42.09 \mathrm{~K}$ \\
\hline 1995 & 2 & & 13 & 1.13 & $1.05 \mathrm{~K}$ & $11.00 \mathrm{~K}$ & $12.05 \mathrm{~K}$ & $129.94 \mathrm{~K}$ & $64.24 \mathrm{~K}$ & $65.70 \mathrm{~K}$ & $39.16 \mathrm{~K}$ \\
\hline 1996 & 3 & & 9 & 1.09 & $1.10 \mathrm{~K}$ & $12.00 \mathrm{~K}$ & $13.10 \mathrm{~K}$ & $141.15 \mathrm{~K}$ & $54.29 \mathrm{~K}$ & $86.87 \mathrm{~K}$ & $34.16 \mathrm{~K}$ \\
\hline 1997 & 4 & & 6 & 1.06 & $1.15 \mathrm{~K}$ & $13.00 \mathrm{~K}$ & $14.15 \mathrm{~K}$ & $153.52 \mathrm{~K}$ & $46.65 \mathrm{~K}$ & $106.87 \mathrm{~K}$ & $31.15 \mathrm{~K}$ \\
\hline 1998 & 5 & & 5 & 1.05 & $1.20 \mathrm{~K}$ & $14.00 \mathrm{~K}$ & $15.20 \mathrm{~K}$ & $165.79 \mathrm{~K}$ & $39.39 \mathrm{~K}$ & $126.40 \mathrm{~K}$ & $29.55 \mathrm{~K}$ \\
\hline 1999 & 6 & & 5 & 1.05 & $1.25 \mathrm{~K}$ & $15.00 \mathrm{~K}$ & $16.25 \mathrm{~K}$ & $178.82 \mathrm{~K}$ & $32.66 \mathrm{~K}$ & $146.16 \mathrm{~K}$ & $28.89 \mathrm{~K}$ \\
\hline 2000 & 7 & & 7 & 1.07 & $1.30 \mathrm{~K}$ & $16.00 \mathrm{~K}$ & $17.30 \mathrm{~K}$ & $185.20 \mathrm{~K}$ & $23.41 \mathrm{~K}$ & $161.79 \mathrm{~K}$ & $30.09 \mathrm{~K}$ \\
\hline 2001 & 8 & & 7 & 1.07 & $1.35 \mathrm{~K}$ & $17.00 \mathrm{~K}$ & $18.35 \mathrm{~K}$ & $195.02 \mathrm{~K}$ & $18.44 \mathrm{~K}$ & $176.58 \mathrm{~K}$ & $29.91 \mathrm{~K}$ \\
\hline 2002 & 9 & & 7 & 1.07 & $1.40 \mathrm{~K}$ & $18.00 \mathrm{~K}$ & $19.40 \mathrm{~K}$ & $208.91 \mathrm{~K}$ & $15.75 \mathrm{~K}$ & $193.15 \mathrm{~K}$ & $29.02 \mathrm{~K}$ \\
\hline 2003 & 10 & & 5 & 1.05 & $1.45 \mathrm{~K}$ & $19.00 \mathrm{~K}$ & $20.45 \mathrm{~K}$ & $225.76 \mathrm{~K}$ & $13.96 \mathrm{~K}$ & $211.81 \mathrm{~K}$ & $28.09 \mathrm{~K}$ \\
\hline 2004 & 11 & & 5 & 1.05 & $1.50 \mathrm{~K}$ & $20.00 \mathrm{~K}$ & $21.50 \mathrm{~K}$ & $244.35 \mathrm{~K}$ & $12.43 \mathrm{~K}$ & $231.93 \mathrm{~K}$ & $27.37 \mathrm{~K}$ \\
\hline 2005 & 12 & & 5 & 1.05 & $1.55 \mathrm{~K}$ & $21.00 \mathrm{~K}$ & $22.55 \mathrm{~K}$ & $256.41 \mathrm{~K}$ & $16.73 \mathrm{~K}$ & $239.68 \mathrm{~K}$ & $26.64 \mathrm{~K}$ \\
\hline 2006 & 13 & & 7 & 1.07 & $1.60 \mathrm{~K}$ & $22.00 \mathrm{~K}$ & $23.60 \mathrm{~K}$ & $246.79 \mathrm{~K}$ & $6.21 \mathrm{~K}$ & $240.58 \mathrm{~K}$ & $28.83 \mathrm{~K}$ \\
\hline 2007 & 14 & & 7 & 1.07 & $1.65 \mathrm{~K}$ & $23.00 \mathrm{~K}$ & $24.65 \mathrm{~K}$ & $252.96 \mathrm{~K}$ & $4.76 \mathrm{~K}$ & $248.20 \mathrm{~K}$ & $29.01 \mathrm{~K}$ \\
\hline 2008 & 15 & & 6 & 1.06 & $1.70 \mathrm{~K}$ & $24.00 \mathrm{~K}$ & $25.70 \mathrm{~K}$ & $273.14 \mathrm{~K}$ & $4.37 \mathrm{~K}$ & $268.77 \mathrm{~K}$ & $28.38 \mathrm{~K}$ \\
\hline 2009 & 16 & & 0 & 1.00 & $1.75 \mathrm{~K}$ & $25.00 \mathrm{~K}$ & $26.75 \mathrm{~K}$ & $399.61 \mathrm{~K}$ & $8.81 \mathrm{~K}$ & $390.81 \mathrm{~K}$ & $25.39 \mathrm{~K}$ \\
\hline 2010 & 17 & & 3 & 1.03 & $1.80 \mathrm{~K}$ & $26.00 \mathrm{~K}$ & $27.80 \mathrm{~K}$ & $362.90 \mathrm{~K}$ & $5.15 \mathrm{~K}$ & $357.75 \mathrm{~K}$ & $26.56 \mathrm{~K}$ \\
\hline 2011 & 18 & & 7 & 1.07 & $1.85 \mathrm{~K}$ & $27.00 \mathrm{~K}$ & $28.85 \mathrm{~K}$ & $290.26 \mathrm{~K}$ & $2.02 \mathrm{~K}$ & $288.24 \mathrm{~K}$ & $28.93 \mathrm{~K}$ \\
\hline 2012 & 19 & & 6 & 1.06 & $1.90 \mathrm{~K}$ & $28.00 \mathrm{~K}$ & $29.90 \mathrm{~K}$ & $322.05 \mathrm{~K}$ & $2.04 \mathrm{~K}$ & $320.02 \mathrm{~K}$ & $28.31 \mathrm{~K}$ \\
\hline 2013 & 20 & & 3 & 1.03 & $1.95 \mathrm{~K}$ & $29.00 \mathrm{~K}$ & $30.95 \mathrm{~K}$ & $411.80 \mathrm{~K}$ & $2.91 \mathrm{~K}$ & $408.89 \mathrm{~K}$ & $27.15 \mathrm{~K}$ \\
\hline 2014 & 21 & & 2 & 1.02 & $2.00 \mathrm{~K}$ & $30.00 \mathrm{~K}$ & $32.00 \mathrm{~K}$ & $469.04 \mathrm{~K}$ & $3.06 \mathrm{~K}$ & $465.98 \mathrm{~K}$ & $26.69 \mathrm{~K}$ \\
\hline
\end{tabular}

Table 7. Decline in apparent rate: MUAI (bus 115)

\begin{tabular}{|c|c|c|c|c|c|c|c|c|c|c|c|}
\hline \multicolumn{9}{|c|}{ Bus 115} & \multirow{2}{*}{$\begin{array}{c}V C[€] \\
\text { Exp. Meth. }\end{array}$} & \multirow{2}{*}{$\begin{array}{c}\text { NPV [€ year } n] \\
\text { Exp. Meth. }\end{array}$} & \multirow{2}{*}{$\begin{array}{c}\text { UAI }[€ \text { year } n] \\
\text { Exp. Meth. }\end{array}$} \\
\hline Year & Year $j$ & $C A[€]$ & $i_{A}[\%]$ & $\left(1+i_{A, j}\right)$ & $C M[€]$ & $\mathrm{CO}[€]$ & $\Sigma_{1}[€]$ & $V P[€]$ & & & \\
\hline 1993 & 0 & $110.66 \mathrm{~K}$ & 8 & & & & & & & & \\
\hline 1994 & 1 & & 8 & 1.08 & $1.00 \mathrm{~K}$ & $10.00 \mathrm{~K}$ & $11.00 \mathrm{~K}$ & $120.85 \mathrm{~K}$ & $87.91 \mathrm{~K}$ & $32.94 \mathrm{~K}$ & $35.56 \mathrm{~K}$ \\
\hline 1995 & 2 & & 8 & 1.08 & $1.05 \mathrm{~K}$ & $11.00 \mathrm{~K}$ & $12.05 \mathrm{~K}$ & $131.25 \mathrm{~K}$ & $70.11 \mathrm{~K}$ & $61.14 \mathrm{~K}$ & $34.16 \mathrm{~K}$ \\
\hline 1996 & 3 & & 8 & 1.08 & $1.10 \mathrm{~K}$ & $12.00 \mathrm{~K}$ & $13.10 \mathrm{~K}$ & $141.84 \mathrm{~K}$ & $56.13 \mathrm{~K}$ & $85.71 \mathrm{~K}$ & $32.98 \mathrm{~K}$ \\
\hline 1997 & 4 & & 7 & 1.07 & $1.15 \mathrm{~K}$ & $13.00 \mathrm{~K}$ & $14.15 \mathrm{~K}$ & $152.63 \mathrm{~K}$ & $45.11 \mathrm{~K}$ & $107.52 \mathrm{~K}$ & $31.98 \mathrm{~K}$ \\
\hline 1998 & 5 & & 7 & 1.07 & $1.20 \mathrm{~K}$ & $14.00 \mathrm{~K}$ & $15.20 \mathrm{~K}$ & $163.52 \mathrm{~K}$ & $36.39 \mathrm{~K}$ & $127.13 \mathrm{~K}$ & $31.11 \mathrm{~K}$ \\
\hline 1999 & 6 & & 7 & 1.07 & $1.25 \mathrm{~K}$ & $15.00 \mathrm{~K}$ & $16.25 \mathrm{~K}$ & $174.80 \mathrm{~K}$ & $29.48 \mathrm{~K}$ & $145.32 \mathrm{~K}$ & $30.41 \mathrm{~K}$ \\
\hline 2000 & 7 & & 7 & 1.07 & $1.30 \mathrm{~K}$ & $16.00 \mathrm{~K}$ & $17.30 \mathrm{~K}$ & $186.22 \mathrm{~K}$ & $23.97 \mathrm{~K}$ & $162.25 \mathrm{~K}$ & $29.80 \mathrm{~K}$ \\
\hline 2001 & 8 & & 7 & 1.07 & $1.35 \mathrm{~K}$ & $17.00 \mathrm{~K}$ & $18.35 \mathrm{~K}$ & $197.90 \mathrm{~K}$ & $19.56 \mathrm{~K}$ & $178.33 \mathrm{~K}$ & $29.29 \mathrm{~K}$ \\
\hline 2002 & 9 & & 6 & 1.06 & $1.40 \mathrm{~K}$ & $18.00 \mathrm{~K}$ & $19.40 \mathrm{~K}$ & $209.87 \mathrm{~K}$ & $16.03 \mathrm{~K}$ & $193.84 \mathrm{~K}$ & $28.87 \mathrm{~K}$ \\
\hline 2003 & 10 & & 6 & 1.06 & $1.45 \mathrm{~K}$ & $19.00 \mathrm{~K}$ & $20.45 \mathrm{~K}$ & $222.17 \mathrm{~K}$ & $13.19 \mathrm{~K}$ & $208.99 \mathrm{~K}$ & $28.52 \mathrm{~K}$ \\
\hline 2004 & 11 & & 6 & 1.06 & $1.50 \mathrm{~K}$ & $20.00 \mathrm{~K}$ & $21.50 \mathrm{~K}$ & $234.85 \mathrm{~K}$ & $10.89 \mathrm{~K}$ & $223.96 \mathrm{~K}$ & $28.23 \mathrm{~K}$ \\
\hline 2005 & 12 & & 6 & 1.06 & $1.55 \mathrm{~K}$ & $21.00 \mathrm{~K}$ & $22.55 \mathrm{~K}$ & $247.96 \mathrm{~K}$ & $9.03 \mathrm{~K}$ & $238.93 \mathrm{~K}$ & $28.00 \mathrm{~K}$ \\
\hline 2006 & 13 & & 5 & 1.05 & $1.60 \mathrm{~K}$ & $22.00 \mathrm{~K}$ & $23.60 \mathrm{~K}$ & $261.54 \mathrm{~K}$ & $7.51 \mathrm{~K}$ & $254.03 \mathrm{~K}$ & $27.82 \mathrm{~K}$ \\
\hline 2007 & 14 & & 5 & 1.05 & $1.65 \mathrm{~K}$ & $23.00 \mathrm{~K}$ & $24.65 \mathrm{~K}$ & $275.67 \mathrm{~K}$ & $6.28 \mathrm{~K}$ & $269.39 \mathrm{~K}$ & $27.68 \mathrm{~K}$ \\
\hline 2008 & 15 & & 5 & 1.05 & $1.70 \mathrm{~K}$ & $24.00 \mathrm{~K}$ & $25.70 \mathrm{~K}$ & $290.41 \mathrm{~K}$ & $5.27 \mathrm{~K}$ & $285.14 \mathrm{~K}$ & $27.59 \mathrm{~K}$ \\
\hline 2009 & 16 & & 5 & 1.05 & $1.75 \mathrm{~K}$ & $25.00 \mathrm{~K}$ & $26.75 \mathrm{~K}$ & $305.83 \mathrm{~K}$ & $4.44 \mathrm{~K}$ & $301.40 \mathrm{~K}$ & $27.53 \mathrm{~K}$ \\
\hline 2010 & 17 & & 5 & 1.05 & $1.80 \mathrm{~K}$ & $26.00 \mathrm{~K}$ & $27.80 \mathrm{~K}$ & $322.03 \mathrm{~K}$ & $3.75 \mathrm{~K}$ & $318.28 \mathrm{~K}$ & $27.50 \mathrm{~K}$ \\
\hline 2011 & 18 & & 4 & 1.04 & $1.85 \mathrm{~K}$ & $27.00 \mathrm{~K}$ & $28.85 \mathrm{~K}$ & $339.08 \mathrm{~K}$ & $3.18 \mathrm{~K}$ & $335.89 \mathrm{~K}$ & $27.51 \mathrm{~K}$ \\
\hline 2012 & 19 & & 4 & 1.04 & $1.90 \mathrm{~K}$ & $28.00 \mathrm{~K}$ & $29.90 \mathrm{~K}$ & $357.09 \mathrm{~K}$ & $2.71 \mathrm{~K}$ & $354.38 \mathrm{~K}$ & $27.54 \mathrm{~K}$ \\
\hline 2013 & 20 & & 4 & 1.04 & $1.95 \mathrm{~K}$ & $29.00 \mathrm{~K}$ & $30.95 \mathrm{~K}$ & $376.18 \mathrm{~K}$ & $2.32 \mathrm{~K}$ & $373.86 \mathrm{~K}$ & $27.61 \mathrm{~K}$ \\
\hline 2014 & 21 & & 4 & 1.04 & $2.00 \mathrm{~K}$ & $30.00 \mathrm{~K}$ & $32.00 \mathrm{~K}$ & $396.46 \mathrm{~K}$ & $1.99 \mathrm{~K}$ & $394.47 \mathrm{~K}$ & $27.69 \mathrm{~K}$ \\
\hline
\end{tabular}




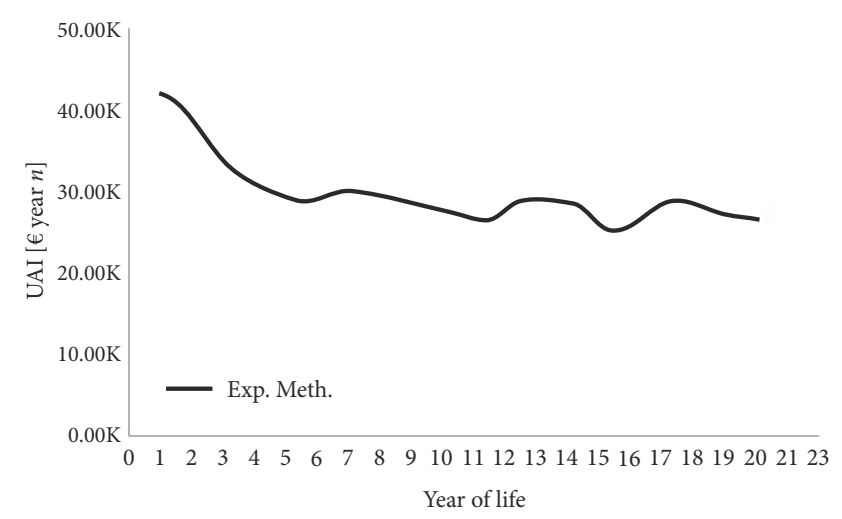

Figure 9. Actual apparent rate: MUAI (bus 115)

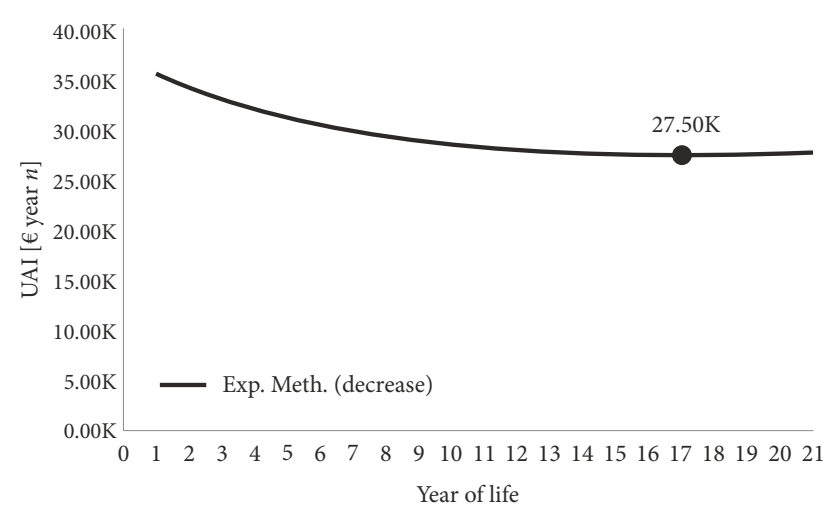

Figure 10. Decline in apparent rate: MUAI (bus 115)

Table 8. Increase in apparent rate: MUAI (bus 115)

\begin{tabular}{|c|c|c|c|c|c|c|c|c|c|c|c|}
\hline \multicolumn{9}{|c|}{ Bus 115} & \multirow{2}{*}{$\begin{array}{c}V C[€] \\
\text { Exp. Meth. }\end{array}$} & \multirow{2}{*}{$\frac{N P V[€ \text { year } n]}{\text { Exp. Meth. }}$} & \multirow{2}{*}{$\frac{U A I[€ \text { year } n]}{\text { Exp. Meth. }}$} \\
\hline Year & Year $j$ & $C A[€]$ & $i_{A}[\%]$ & $\left(1+i_{A, j}\right)$ & $C M[€]$ & $\mathrm{CO}[€]$ & $\Sigma_{1}[€]$ & $V P[€]$ & & & \\
\hline 1993 & 0 & $110.66 \mathrm{~K}$ & 8 & & & & & & & & \\
\hline 1994 & 1 & & 8 & 1.08 & $1.00 \mathrm{~K}$ & $10.00 \mathrm{~K}$ & $11.00 \mathrm{~K}$ & $120.81 \mathrm{~K}$ & $87.57 \mathrm{~K}$ & $33.24 \mathrm{~K}$ & $36.02 \mathrm{~K}$ \\
\hline 1995 & 2 & & 9 & 1.09 & $1.05 \mathrm{~K}$ & $11.00 \mathrm{~K}$ & $12.05 \mathrm{~K}$ & $131.01 \mathrm{~K}$ & $69.04 \mathrm{~K}$ & $61.97 \mathrm{~K}$ & $35.03 \mathrm{~K}$ \\
\hline 1996 & 3 & & 9 & 1.09 & $1.10 \mathrm{~K}$ & $12.00 \mathrm{~K}$ & $13.10 \mathrm{~K}$ & $141.13 \mathrm{~K}$ & $54.22 \mathrm{~K}$ & $86.91 \mathrm{~K}$ & $34.20 \mathrm{~K}$ \\
\hline 1997 & 4 & & 9 & 1.09 & $1.15 \mathrm{~K}$ & $13.00 \mathrm{~K}$ & $14.15 \mathrm{~K}$ & $151.04 \mathrm{~K}$ & $42.42 \mathrm{~K}$ & $108.62 \mathrm{~K}$ & $33.52 \mathrm{~K}$ \\
\hline 1998 & 5 & & 9 & 1.09 & $1.20 \mathrm{~K}$ & $14.00 \mathrm{~K}$ & $15.20 \mathrm{~K}$ & $160.71 \mathrm{~K}$ & $33.06 \mathrm{~K}$ & $127.65 \mathrm{~K}$ & $32.99 \mathrm{~K}$ \\
\hline 1999 & 6 & & 9 & 1.09 & $1.25 \mathrm{~K}$ & $15.00 \mathrm{~K}$ & $16.25 \mathrm{~K}$ & $169.82 \mathrm{~K}$ & $25.66 \mathrm{~K}$ & $144.16 \mathrm{~K}$ & $32.53 \mathrm{~K}$ \\
\hline 2000 & 7 & & 10 & 1.10 & $1.30 \mathrm{~K}$ & $16.00 \mathrm{~K}$ & $17.30 \mathrm{~K}$ & $178.53 \mathrm{~K}$ & $19.85 \mathrm{~K}$ & $158.68 \mathrm{~K}$ & $32.19 \mathrm{~K}$ \\
\hline 2001 & 8 & & 10 & 1.10 & $1.35 \mathrm{~K}$ & $17.00 \mathrm{~K}$ & $18.35 \mathrm{~K}$ & $186.69 \mathrm{~K}$ & $15.29 \mathrm{~K}$ & $171.39 \mathrm{~K}$ & $31.93 \mathrm{~K}$ \\
\hline 2002 & 9 & & 10 & 1.10 & $1.40 \mathrm{~K}$ & $18.00 \mathrm{~K}$ & $19.40 \mathrm{~K}$ & $194.25 \mathrm{~K}$ & $11.74 \mathrm{~K}$ & $182.51 \mathrm{~K}$ & $31.74 \mathrm{~K}$ \\
\hline 2003 & 10 & & 10 & 1.10 & $1.45 \mathrm{~K}$ & $19.00 \mathrm{~K}$ & $20.45 \mathrm{~K}$ & $201.19 \mathrm{~K}$ & $8.98 \mathrm{~K}$ & $192.22 \mathrm{~K}$ & $31.62 \mathrm{~K}$ \\
\hline 2004 & 11 & & 10 & 1.10 & $1.50 \mathrm{~K}$ & $20.00 \mathrm{~K}$ & $21.50 \mathrm{~K}$ & $207.49 \mathrm{~K}$ & $6.84 \mathrm{~K}$ & $200.65 \mathrm{~K}$ & $31.55 \mathrm{~K}$ \\
\hline 2005 & 12 & & 11 & 1.11 & $1.55 \mathrm{~K}$ & $21.00 \mathrm{~K}$ & $22.55 \mathrm{~K}$ & $213.13 \mathrm{~K}$ & $5.19 \mathrm{~K}$ & $207.94 \mathrm{~K}$ & $31.53 \mathrm{~K}$ \\
\hline 2006 & 13 & & 11 & 1.11 & $1.60 \mathrm{~K}$ & $22.00 \mathrm{~K}$ & $23.60 \mathrm{~K}$ & $218.12 \mathrm{~K}$ & $3.92 \mathrm{~K}$ & $214.20 \mathrm{~K}$ & $31.54 \mathrm{~K}$ \\
\hline 2007 & 14 & & 11 & 1.11 & $1.65 \mathrm{~K}$ & $23.00 \mathrm{~K}$ & $24.65 \mathrm{~K}$ & $222.47 \mathrm{~K}$ & $2.95 \mathrm{~K}$ & $219.52 \mathrm{~K}$ & $31.59 \mathrm{~K}$ \\
\hline 2008 & 15 & & 11 & 1.11 & $1.70 \mathrm{~K}$ & $24.00 \mathrm{~K}$ & $25.70 \mathrm{~K}$ & $226.20 \mathrm{~K}$ & $2.22 \mathrm{~K}$ & $223.98 \mathrm{~K}$ & $31.67 \mathrm{~K}$ \\
\hline 2009 & 16 & & 12 & 1.12 & $1.75 \mathrm{~K}$ & $25.00 \mathrm{~K}$ & $26.75 \mathrm{~K}$ & $229.33 \mathrm{~K}$ & $1.66 \mathrm{~K}$ & $227.67 \mathrm{~K}$ & $31.77 \mathrm{~K}$ \\
\hline 2010 & 17 & & 12 & 1.12 & $1.80 \mathrm{~K}$ & $26.00 \mathrm{~K}$ & $27.80 \mathrm{~K}$ & $231.89 \mathrm{~K}$ & $1.23 \mathrm{~K}$ & $230.65 \mathrm{~K}$ & $31.89 \mathrm{~K}$ \\
\hline 2011 & 18 & & 12 & 1.12 & $1.85 \mathrm{~K}$ & $27.00 \mathrm{~K}$ & $28.85 \mathrm{~K}$ & $233.92 \mathrm{~K}$ & $0.92 \mathrm{~K}$ & $233.00 \mathrm{~K}$ & $32.02 \mathrm{~K}$ \\
\hline 2012 & 19 & & 12 & 1.12 & $1.90 \mathrm{~K}$ & $28.00 \mathrm{~K}$ & $29.90 \mathrm{~K}$ & $235.45 \mathrm{~K}$ & $0.68 \mathrm{~K}$ & $234.78 \mathrm{~K}$ & $32.16 \mathrm{~K}$ \\
\hline 2013 & 20 & & 12 & 1.12 & $1.95 \mathrm{~K}$ & $29.00 \mathrm{~K}$ & $30.95 \mathrm{~K}$ & $236.53 \mathrm{~K}$ & $0.50 \mathrm{~K}$ & $236.03 \mathrm{~K}$ & $32.32 \mathrm{~K}$ \\
\hline 2014 & 21 & & 13 & 1.13 & $2.00 \mathrm{~K}$ & $30.00 \mathrm{~K}$ & $32.00 \mathrm{~K}$ & $237.20 \mathrm{~K}$ & $0.37 \mathrm{~K}$ & $236.83 \mathrm{~K}$ & $32.48 \mathrm{~K}$ \\
\hline
\end{tabular}

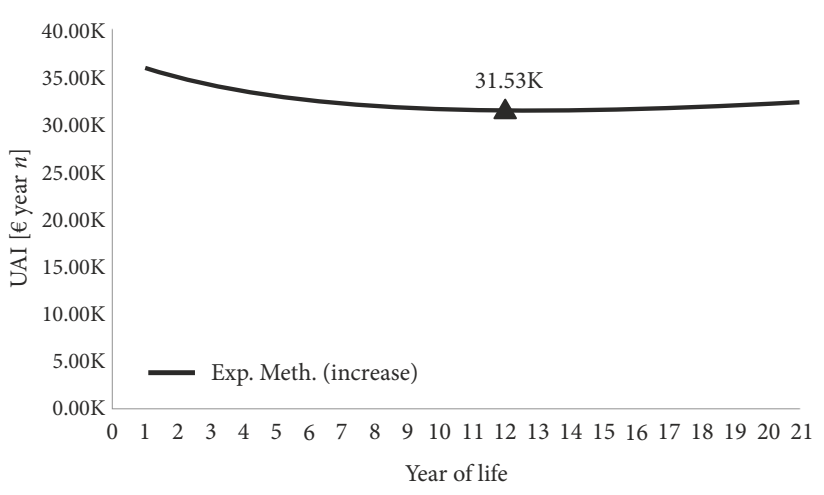

Figure 11. Increase in the apparent rate: UAI (bus 115)

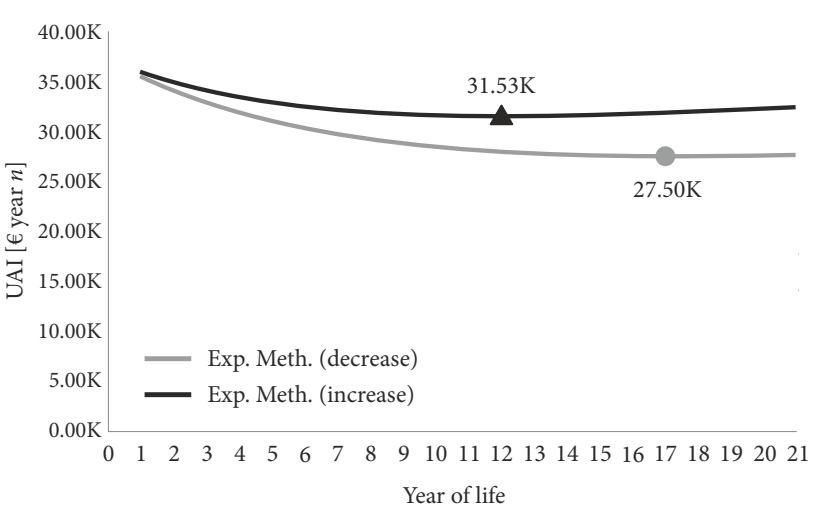

Figure 12. Apparent rate variation influence on the MUAI (bus 115) 
Figure 12 verifies the influence of the high apparent rate in the econometric models. An increase or decrease in the apparent rate over time causes the withdrawal point to vary. The replacement point can vary by more than five years; i.e., the replacement point is 12 years if the apparent rate increases over time, but if the apparent rate decreases, the replacement point is 18 years. As mentioned above, the increase in annual income of the bus is also evident. Thus, it can be stated that the replacement period varies considerably with the apparent rate, influencing the final decision of the manager.

\section{Influence of fuel cost variables}

Variations in oil prices in international markets influence transportation costs, as the costs of most means of transport are directly linked to the price of a barrel of crude oil. Therefore, the cost to transport a particular product can vary greatly depending on the market fuel prices. The price of fuel is conditioned by several external factors worldwide, especially in OPEC countries. The Figures 13 and 14 shows the average price variation of fuel (diesel) from 2003 to 2014 .
As Figure 13 suggests, the average price varies greatly, but over the study interval, there is an increasing trend. Figure 14 shows the operating costs of a bus taking into account the price of diesel fuel for 2003-2014.

The Tables 9, 10 and Figures 15, 16 that follow indicate the influence of the price of diesel fuel on bus replacement time. In the first example, Table 9 and Figure 15 show the effect of rising costs on the replacement time of bus 115 . Note that the highest costs occur between 2003 and 2014. The cost in 2012 is the average cost.

As the Table and Figure 15 show, the replacement point is located in the 14 th year, and the UAI is $27.65 \mathrm{~K}$. This calculation demonstrates that an increase in the price of diesel fuel influences the replacement time of an urban bus used for public transport.

We now turn to calculations showing what happens if the cost of diesel drops. Table 10 and Figure 16 show the effect of a decline in the price of diesel fuel on the replacement time for bus 115 .

The Table 10 and Figure 16 determine the replacement point as occurring in the 18th year of life, taking into account the price of diesel in 2014, when it is lower by about 0.11 cents than in 2012 . The UAI is $27.58 \mathrm{~K}$.

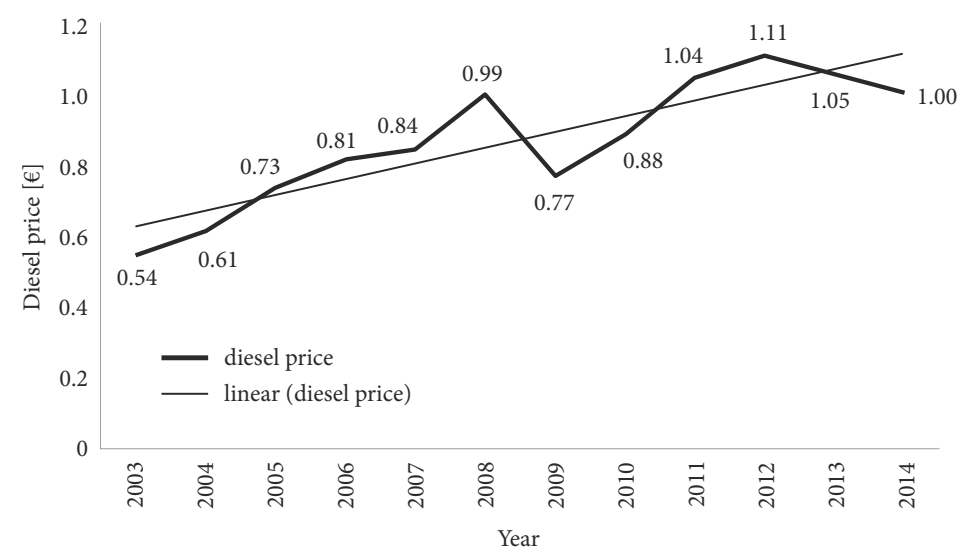

Figure 13. Variation in cost of diesel between 2003 and 2014

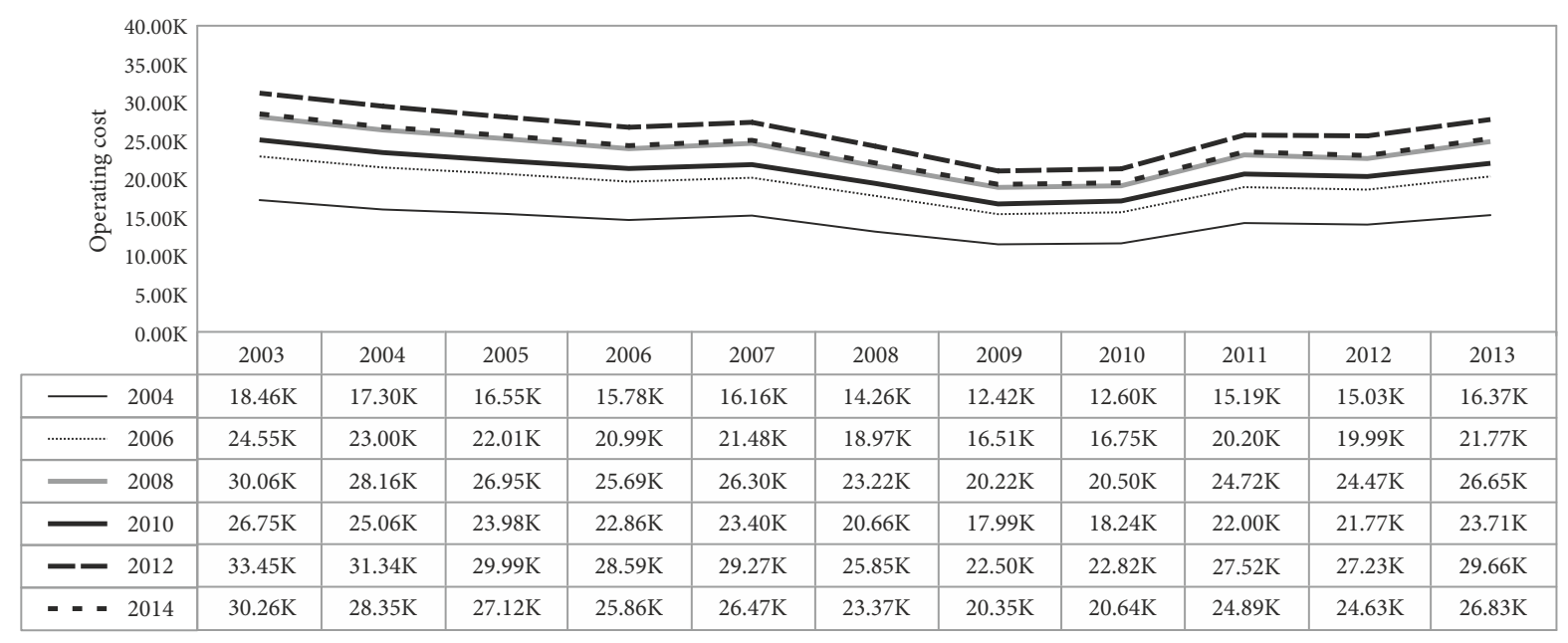

Figure 14. Operating cost of bus versus price of fuel 
Table 9. Increase in price of diesel: MUAI (bus 115)

\begin{tabular}{|c|c|c|c|c|c|c|c|c|c|c|}
\hline \multicolumn{8}{|c|}{ Bus 115} & \multirow{2}{*}{$\frac{V C[€]}{\text { Exp. Meth. }}$} & \multirow{2}{*}{$\frac{N P V[€ \text { year } n]}{\text { Exp. Meth. }}$} & \multirow{2}{*}{$\frac{U A I[€ \text { year } n]}{\text { Exp. Meth. }}$} \\
\hline Year & Year $j$ & $C A[€]$ & $i_{A}[\%]$ & $\left(1+i_{A, j}\right)$ & $C M[€]$ & $\mathrm{CO}[€]$ & $\sum_{1}[€]$ & & & \\
\hline 1993 & 0 & $110.66 \mathrm{~K}$ & & & & & & & & \\
\hline 1994 & 1 & & 1.08 & $1.00 \mathrm{~K}$ & $11.22 \mathrm{~K}$ & $12.22 \mathrm{~K}$ & $121.96 \mathrm{~K}$ & $87.74 \mathrm{~K}$ & $34.22 \mathrm{~K}$ & $37.01 \mathrm{~K}$ \\
\hline 1995 & 2 & & 1.08 & $1.05 \mathrm{~K}$ & $10.71 \mathrm{~K}$ & $11.76 \mathrm{~K}$ & $132.01 \mathrm{~K}$ & $69.57 \mathrm{~K}$ & $62.44 \mathrm{~K}$ & $35.09 \mathrm{~K}$ \\
\hline 1996 & 3 & & 1.08 & $1.10 \mathrm{~K}$ & $10.46 \mathrm{~K}$ & $11.56 \mathrm{~K}$ & $141.15 \mathrm{~K}$ & $55.16 \mathrm{~K}$ & $85.99 \mathrm{~K}$ & $33.46 \mathrm{~K}$ \\
\hline 1997 & 4 & & 1.08 & $1.15 \mathrm{~K}$ & $10.48 \mathrm{~K}$ & $11.63 \mathrm{~K}$ & $149.65 \mathrm{~K}$ & $43.74 \mathrm{~K}$ & $105.91 \mathrm{~K}$ & $32.09 \mathrm{~K}$ \\
\hline 1998 & 5 & & 1.08 & $1.20 \mathrm{~K}$ & $10.76 \mathrm{~K}$ & $11.96 \mathrm{~K}$ & $157.73 \mathrm{~K}$ & $34.68 \mathrm{~K}$ & $123.05 \mathrm{~K}$ & $30.95 \mathrm{~K}$ \\
\hline 1999 & 6 & & 1.08 & $1.25 \mathrm{~K}$ & $11.31 \mathrm{~K}$ & $12.56 \mathrm{~K}$ & $165.58 \mathrm{~K}$ & $27.50 \mathrm{~K}$ & $138.08 \mathrm{~K}$ & $30.01 \mathrm{~K}$ \\
\hline 2000 & 7 & & 1.08 & $1.30 \mathrm{~K}$ & $12.12 \mathrm{~K}$ & $13.42 \mathrm{~K}$ & $173.32 \mathrm{~K}$ & $21.80 \mathrm{~K}$ & $151.52 \mathrm{~K}$ & $29.26 \mathrm{~K}$ \\
\hline 2001 & 8 & & 1.08 & $1.35 \mathrm{~K}$ & $13.19 \mathrm{~K}$ & $14.54 \mathrm{~K}$ & $181.09 \mathrm{~K}$ & $17.29 \mathrm{~K}$ & $163.80 \mathrm{~K}$ & $28.68 \mathrm{~K}$ \\
\hline 2002 & 9 & & 1.08 & $1.40 \mathrm{~K}$ & $14.53 \mathrm{~K}$ & $15.93 \mathrm{~K}$ & $188.95 \mathrm{~K}$ & $13.71 \mathrm{~K}$ & $175.24 \mathrm{~K}$ & $28.24 \mathrm{~K}$ \\
\hline 2003 & 10 & & 1.08 & $1.45 \mathrm{~K}$ & $15.54 \mathrm{~K}$ & $16.99 \mathrm{~K}$ & $196.70 \mathrm{~K}$ & $10.87 \mathrm{~K}$ & $185.83 \mathrm{~K}$ & $27.90 \mathrm{~K}$ \\
\hline 2004 & 11 & & 1.08 & $1.50 \mathrm{~K}$ & $18.46 \mathrm{~K}$ & $19.96 \mathrm{~K}$ & $205.13 \mathrm{~K}$ & $8.62 \mathrm{~K}$ & $196.51 \mathrm{~K}$ & $27.74 \mathrm{~K}$ \\
\hline 2005 & 12 & & 1.08 & $1.55 \mathrm{~K}$ & $20.75 \mathrm{~K}$ & $22.30 \mathrm{~K}$ & $213.83 \mathrm{~K}$ & $6.83 \mathrm{~K}$ & $206.99 \mathrm{~K}$ & $27.70 \mathrm{~K}$ \\
\hline 2006 & 13 & & 1.08 & $1.60 \mathrm{~K}$ & $22.01 \mathrm{~K}$ & $23.61 \mathrm{~K}$ & $222.34 \mathrm{~K}$ & $5.42 \mathrm{~K}$ & $216.92 \mathrm{~K}$ & $27.69 \mathrm{~K}$ \\
\hline 2007 & 14 & & 1.08 & $1.65 \mathrm{~K}$ & $21.73 \mathrm{~K}$ & $23.38 \mathrm{~K}$ & $230.14 \mathrm{~K}$ & $4.30 \mathrm{~K}$ & $225.84 \mathrm{~K}$ & $27.65 \mathrm{~K}$ \\
\hline 2008 & 15 & & 1.08 & $1.70 \mathrm{~K}$ & $29.27 \mathrm{~K}$ & $30.97 \mathrm{~K}$ & $239.69 \mathrm{~K}$ & $3.41 \mathrm{~K}$ & $236.28 \mathrm{~K}$ & $27.88 \mathrm{~K}$ \\
\hline 2009 & 16 & & 1.08 & $1.75 \mathrm{~K}$ & $25.85 \mathrm{~K}$ & $27.60 \mathrm{~K}$ & $247.56 \mathrm{~K}$ & $2.70 \mathrm{~K}$ & $244.86 \mathrm{~K}$ & $27.95 \mathrm{~K}$ \\
\hline 2010 & 17 & & 1.08 & $1.80 \mathrm{~K}$ & $22.50 \mathrm{~K}$ & $24.30 \mathrm{~K}$ & $253.96 \mathrm{~K}$ & $2.14 \mathrm{~K}$ & $251.82 \mathrm{~K}$ & $27.90 \mathrm{~K}$ \\
\hline 2011 & 18 & & 1.08 & $1.85 \mathrm{~K}$ & $22.82 \mathrm{~K}$ & $24.67 \mathrm{~K}$ & $259.97 \mathrm{~K}$ & $1.70 \mathrm{~K}$ & $258.27 \mathrm{~K}$ & $27.87 \mathrm{~K}$ \\
\hline 2012 & 19 & & 1.08 & $1.90 \mathrm{~K}$ & $27.52 \mathrm{~K}$ & $29.42 \mathrm{~K}$ & $266.60 \mathrm{~K}$ & $1.35 \mathrm{~K}$ & $265.25 \mathrm{~K}$ & $27.94 \mathrm{~K}$ \\
\hline 2013 & 20 & & 1.08 & $1.95 \mathrm{~K}$ & $27.23 \mathrm{~K}$ & $29.18 \mathrm{~K}$ & $272.68 \mathrm{~K}$ & $1.07 \mathrm{~K}$ & $271.61 \mathrm{~K}$ & $27.99 \mathrm{~K}$ \\
\hline 2014 & 21 & & 1.08 & $2.00 \mathrm{~K}$ & $29.66 \mathrm{~K}$ & $31.66 \mathrm{~K}$ & $278.78 \mathrm{~K}$ & $0.85 \mathrm{~K}$ & $277.93 \mathrm{~K}$ & $28.09 \mathrm{~K}$ \\
\hline
\end{tabular}

Table 10. Decline in price of diesel: MUAI (bus 115)

\begin{tabular}{|c|c|c|c|c|c|c|c|c|c|c|c|}
\hline \multicolumn{9}{|c|}{ Bus 115} & \multirow{2}{*}{$\begin{array}{c}V C[€] \\
\text { Exp. Meth. }\end{array}$} & \multirow{2}{*}{$\frac{N P V[€ \text { year } n]}{\text { Exp. Meth. }}$} & \multirow{2}{*}{$\frac{U A I[€ \text { year } n]}{\text { Exp. Meth. }}$} \\
\hline Year & Year $j$ & $C A[€]$ & $i_{A}[\%]$ & $\left(1+i_{A, j}\right)$ & $C M[€]$ & $\mathrm{CO}[€]$ & $\Sigma_{1}[€]$ & $V P[€]$ & & & \\
\hline 1993 & 0 & $110.66 \mathrm{~K}$ & 8 & & & & & & & & \\
\hline 1994 & 1 & & 8 & 1.08 & $1.00 \mathrm{~K}$ & $11.22 \mathrm{~K}$ & $12.22 \mathrm{~K}$ & $121.96 \mathrm{~K}$ & $87.74 \mathrm{~K}$ & $34.22 \mathrm{~K}$ & $37.01 \mathrm{~K}$ \\
\hline 1995 & 2 & & 8 & 1.08 & $1.05 \mathrm{~K}$ & $10.71 \mathrm{~K}$ & $11.76 \mathrm{~K}$ & $132.01 \mathrm{~K}$ & $69.57 \mathrm{~K}$ & $62.44 \mathrm{~K}$ & $35.09 \mathrm{~K}$ \\
\hline 1996 & 3 & & 8 & 1.08 & $1.10 \mathrm{~K}$ & $10.46 \mathrm{~K}$ & $11.56 \mathrm{~K}$ & $141.15 \mathrm{~K}$ & $55.16 \mathrm{~K}$ & $85.99 \mathrm{~K}$ & $33.46 \mathrm{~K}$ \\
\hline 1997 & 4 & & 8 & 1.08 & $1.15 \mathrm{~K}$ & $10.48 \mathrm{~K}$ & $11.63 \mathrm{~K}$ & $149.65 \mathrm{~K}$ & $43.74 \mathrm{~K}$ & $105.91 \mathrm{~K}$ & $32.09 \mathrm{~K}$ \\
\hline 1998 & 5 & & 8 & 1.08 & $1.20 \mathrm{~K}$ & $10.76 \mathrm{~K}$ & $11.96 \mathrm{~K}$ & $157.73 \mathrm{~K}$ & $34.68 \mathrm{~K}$ & $123.05 \mathrm{~K}$ & $30.95 \mathrm{~K}$ \\
\hline 1999 & 6 & & 8 & 1.08 & $1.25 \mathrm{~K}$ & $11.31 \mathrm{~K}$ & $12.56 \mathrm{~K}$ & $165.58 \mathrm{~K}$ & $27.50 \mathrm{~K}$ & $138.08 \mathrm{~K}$ & $30.01 \mathrm{~K}$ \\
\hline 2000 & 7 & & 8 & 1.08 & $1.30 \mathrm{~K}$ & $12.12 \mathrm{~K}$ & $13.42 \mathrm{~K}$ & $173.32 \mathrm{~K}$ & $21.80 \mathrm{~K}$ & $151.52 \mathrm{~K}$ & $29.26 \mathrm{~K}$ \\
\hline 2001 & 8 & & 8 & 1.08 & $1.35 \mathrm{~K}$ & $13.19 \mathrm{~K}$ & $14.54 \mathrm{~K}$ & $181.09 \mathrm{~K}$ & $17.29 \mathrm{~K}$ & $163.80 \mathrm{~K}$ & $28.68 \mathrm{~K}$ \\
\hline 2002 & 9 & & 8 & 1.08 & $1.40 \mathrm{~K}$ & $14.53 \mathrm{~K}$ & $15.93 \mathrm{~K}$ & $188.95 \mathrm{~K}$ & $13.71 \mathrm{~K}$ & $175.24 \mathrm{~K}$ & $28.24 \mathrm{~K}$ \\
\hline 2003 & 10 & & 8 & 1.08 & $1.45 \mathrm{~K}$ & $15.54 \mathrm{~K}$ & $16.99 \mathrm{~K}$ & $196.70 \mathrm{~K}$ & $10.87 \mathrm{~K}$ & $185.83 \mathrm{~K}$ & $27.90 \mathrm{~K}$ \\
\hline 2004 & 11 & & 8 & 1.08 & $1.50 \mathrm{~K}$ & $18.46 \mathrm{~K}$ & $19.96 \mathrm{~K}$ & $205.13 \mathrm{~K}$ & $8.62 \mathrm{~K}$ & $196.51 \mathrm{~K}$ & $27.74 \mathrm{~K}$ \\
\hline 2005 & 12 & & 8 & 1.08 & $1.55 \mathrm{~K}$ & $20.75 \mathrm{~K}$ & $22.30 \mathrm{~K}$ & $213.83 \mathrm{~K}$ & $6.83 \mathrm{~K}$ & $206.99 \mathrm{~K}$ & $27.70 \mathrm{~K}$ \\
\hline 2006 & 13 & & 8 & 1.08 & $1.60 \mathrm{~K}$ & $22.01 \mathrm{~K}$ & $23.61 \mathrm{~K}$ & $222.34 \mathrm{~K}$ & $5.42 \mathrm{~K}$ & $216.92 \mathrm{~K}$ & $27.69 \mathrm{~K}$ \\
\hline 2007 & 14 & & 8 & 1.08 & $1.65 \mathrm{~K}$ & $21.73 \mathrm{~K}$ & $23.38 \mathrm{~K}$ & $230.14 \mathrm{~K}$ & $4.30 \mathrm{~K}$ & $225.84 \mathrm{~K}$ & $27.65 \mathrm{~K}$ \\
\hline 2008 & 15 & & 8 & 1.08 & $1.70 \mathrm{~K}$ & $26.47 \mathrm{~K}$ & $28.17 \mathrm{~K}$ & $238.83 \mathrm{~K}$ & $3.41 \mathrm{~K}$ & $235.42 \mathrm{~K}$ & $27.77 \mathrm{~K}$ \\
\hline 2009 & 16 & & 8 & 1.08 & $1.75 \mathrm{~K}$ & $23.37 \mathrm{~K}$ & $25.12 \mathrm{~K}$ & $245.99 \mathrm{~K}$ & $2.70 \mathrm{~K}$ & $243.29 \mathrm{~K}$ & $27.77 \mathrm{~K}$ \\
\hline 2010 & 17 & & 8 & 1.08 & $1.80 \mathrm{~K}$ & $20.35 \mathrm{~K}$ & $22.15 \mathrm{~K}$ & $251.83 \mathrm{~K}$ & $2.14 \mathrm{~K}$ & $249.68 \mathrm{~K}$ & $27.67 \mathrm{~K}$ \\
\hline 2011 & 18 & & 8 & 1.08 & $1.85 \mathrm{~K}$ & $20.64 \mathrm{~K}$ & $22.49 \mathrm{~K}$ & $257.31 \mathrm{~K}$ & $1.70 \mathrm{~K}$ & $255.61 \mathrm{~K}$ & $27.58 \mathrm{~K}$ \\
\hline 2012 & 19 & & 8 & 1.08 & $1.90 \mathrm{~K}$ & \begin{tabular}{|l|}
$24.89 \mathrm{~K}$ \\
\end{tabular} & $26.79 \mathrm{~K}$ & $263.34 \mathrm{~K}$ & $1.35 \mathrm{~K}$ & $261.99 \mathrm{~K}$ & $27.60 \mathrm{~K}$ \\
\hline 2013 & 20 & & 8 & 1.08 & $1.95 \mathrm{~K}$ & $24.63 \mathrm{~K}$ & $26.58 \mathrm{~K}$ & $268.88 \mathrm{~K}$ & $1.07 \mathrm{~K}$ & $267.81 \mathrm{~K}$ & $27.60 \mathrm{~K}$ \\
\hline 2014 & 21 & & 8 & 1.08 & $2.00 \mathrm{~K}$ & $26.83 \mathrm{~K}$ & $28.83 \mathrm{~K}$ & $274.43 \mathrm{~K}$ & $0.85 \mathrm{~K}$ & $273.58 \mathrm{~K}$ & $27.65 \mathrm{~K}$ \\
\hline
\end{tabular}




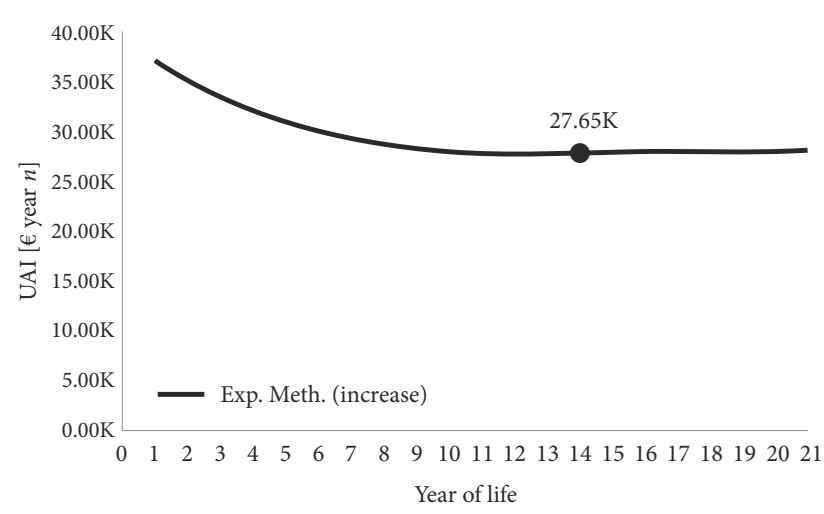

Figure 15. Increase in price of diesel: MUAI (bus 115)

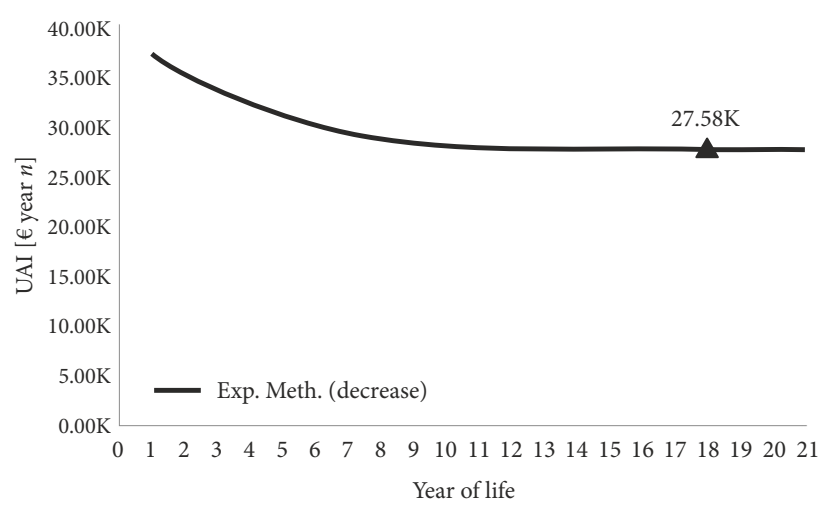

Figure 16. Decline in price of diesel: MUAI (bus 115)

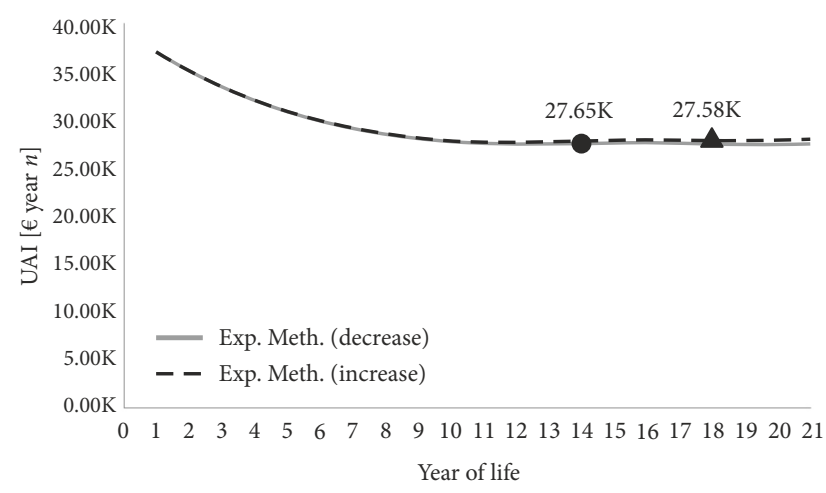

Figure 17. Influences of price of diesel on MUAI (bus 115)

Figure 17 shows the influence of the diesel price on the replacement time for bus 115. An increase or decrease in the cost of diesel over the years under consideration causes the point of withdrawal to vary. According to the Figure 17, the replacement point may vary by four years, if the average diesel prices between 2012 and 2014 are taken as a reference. There is also an increase in the UAI of the bus. For example, the company would have saved 2631.31 $€$ or $2.63 \mathrm{~K}$ on fuel for that bus in 2012 if the average price of diesel was the same as the average price in 2014 .

In other words, the replacement period varies considerably with the price of diesel, affecting the manager's final decision.

\section{Condition-based maintenance versus reserve fleet}

The development and implementation of a policy to support strategies based on CM and, in particular, predictive maintenance, imply the consolidation of several monitoring systems. For example, a bus's Engine Control Unit (ECU) can monitor several variables, such as engine temperature, gearbox, engine speed, fuel consumption, etc.

Monitoring the bus "health" by determining the condition of certain variables implies a subsequent decrease or increase in maintenance intervals, usually the latter, with the following implications:

- eliminating unnecessary disassembly for inspection, thereby increasing the availability of the vehicle and decreasing the maintenance costs;

- reducing unplanned maintenance, thus increasing the availability of the vehicle and decreasing the maintenance costs;

- reducing serious breakdowns in service, thereby increasing bus reliability and, consequently, decreasing bus unavailability and immobilization costs;

- detecting problems before they become critical, reducing intervention costs;

- increasing useful life of the components and the bus, thus increasing profitability.

A variable that must be taken into account in econometric models to replace equipment is the cost of maintenance. This variable is very relevant in determining the optimum time of replacement of any equipment, in this case an urban passenger bus. One of the advantages of predictive maintenance based on oil analysis is the reduction of maintenance costs, and maintenance policy influences replacement time. Monitoring the degradation of oil influences the maintenance KPI's, namely, the Mean Time to Repair (MTTR) and Mean Time Between Failure (MTBF): lower MTTR and higher MTBF values indicate that maintenance is supporting well the production operations. The following equations express the availability $A$, the MTTR and the MTBF respectively:

$$
\begin{aligned}
& A=\frac{M T B F}{M T B F+M T T R} ; \\
& M T T R=M T B F \cdot \frac{(1-A)}{A} ; \\
& M T B F=\frac{M T T R}{\frac{(1-A)}{A}}
\end{aligned}
$$

Table 11 and Figure 18 show that when MTTR decreases, bus availability increases.

The Table 11 and Figure 18 clearly demonstrate that a policy of CM or predictive maintenance leads to a higher MTBF and a lower MTTR. This, in turn, increases the availability of the bus. It is obviously important to demonstrate the effect of the interaction of these indicators on the size of the reserve fleet.

Table 12 and Figure 19 show variations in the size of the reserve fleet according to MTTR. 
Table 11. Availability versus MTTR

\begin{tabular}{|c|c|c|}
\hline Availability [\%] & MTBF [days] & MTTR [days] \\
\hline 70.0 & 365 & 156 \\
\hline 75.0 & 365 & 122 \\
\hline 80.0 & 365 & 91 \\
\hline 85.0 & 365 & 64 \\
\hline 90.0 & 365 & 41 \\
\hline 95.0 & 365 & 19 \\
\hline 96.0 & 365 & 15 \\
\hline 97.0 & 365 & 11 \\
\hline 98.0 & 365 & 7 \\
\hline 99.0 & 365 & 4 \\
\hline
\end{tabular}

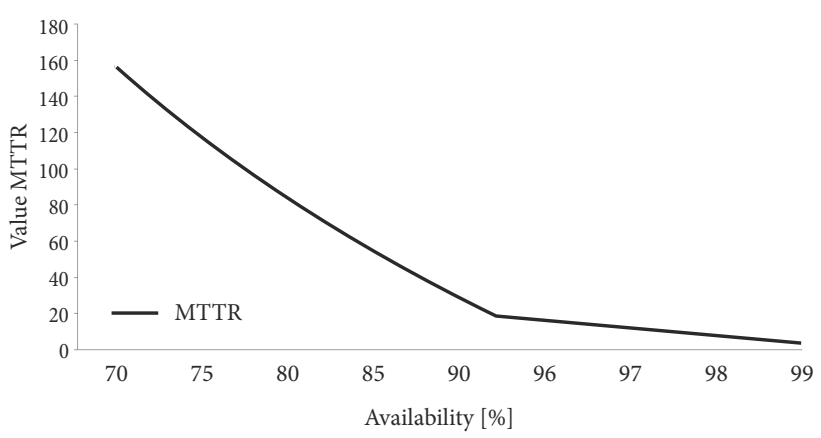

Figure 18. MTTR versus reserve fleet

To determine the size of the reserve fleet, the following calculation can be used:

$$
R F=\frac{m \cdot M T T R}{k},
$$

where: $R F$ - reserve fleet; $m$ - number of fleet buses; MTTR - mean time to repair; $k$ - number of days per year.

According to Table 12 and Figure 19, the size of the reserve fleet increases with an increased MTTR. The lower this indicator, the lower the company's investment in a reserve fleet. Clearly, maintenance indicators and the maintenance policies practiced by road transport companies have an enormous impact in it.

\section{An integrative approach to evaluate reserve fleet}

After the presentation of the several econometric models and the examples based on real data, that allowed to demonstrate their importance, next, we present their synthesis and an integrative approach to them.

First, we presented the global models, namely the UAI, with RPV, and the MMTAC-RPV. From the first and second methods, the years of withdrawal are well defined, within the time interval considered. From the third method the withdrawal time appears outside of it, for the apparent rate considered. It may be concluded that, for this type of equipment, the withdrawal time may vary a lot according to the econometric model considered, what can be verified in practice.
Table 12. MTTR versus reserve fleet

\begin{tabular}{|c|c|c|c|}
\hline MTTR [days] & Bus fleet $[\mathrm{m}]$ & Reserve fleet $R F$ & Interval \\
\hline 5 & 100 & 1.4 & {$[1,2]$} \\
\hline 10 & 100 & 2.7 & {$[2,3]$} \\
\hline 15 & 100 & 4.1 & {$[4,5]$} \\
\hline 20 & 100 & 5.5 & {$[5,6]$} \\
\hline 25 & 100 & 6.8 & {$[6,7]$} \\
\hline 30 & 100 & 8.2 & {$[8,9]$} \\
\hline
\end{tabular}

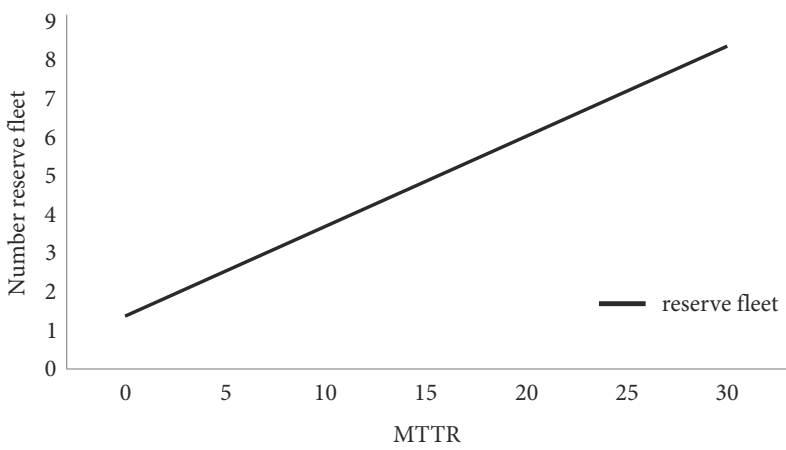

Figure 19. MTTR versus reserve fleet

Next it was studied the influence of the $R O I_{a}$ versus withdrawal time, in which it can be concluded that may have an enlarged time since the $R O I_{a}$ crosses the costs curves until that time.

In the next sections the influence of apparent rate, i.e., inflation and real discount rate, and the fuel price in the withdrawal time were discussed. It can be concluded that these variables have a big influence in this time.

Finally, the influence of the maintenance policy in the withdrawal time, namely in the MTTR interval was discussed, not only because its relevance in the buses availability, but also in the reserve fleet. This happens because the MTTR relates directly with the maintenance costs and, obviously, with the withdrawal time. The variation in MTTR have great influence in the fleet reserve dimension and value, because the high cost of each bus. As MTTR decreases it implies to have less buses in the reserve fleet, what represents a diminishing of thousands of monetary units in its cost.

Based on the presented models and variables studied, it is possible to make many other analysis, and to reach results within a wide spectrum of results in time, in order to get the most rational management.

The results show that it is necessary to accompany carefully, and systematically, this type of equipment in order to reach the most rational decision to withdrawal buses and to dimension the reserve fleet.

The global approaches to determining bus withdrawal can be synthesised as follows:

- econometric models for determining the minimum value of LCC:

- UAI, taking into account the following variables:

- operating cost:

- maintenance costs; 
- fuel costs;

- replacement value;

- inflation rate;

- real discount rate;

- useful life, taking into account the following variables:

- operating costs:

- maintenance costs;

- fuel costs;

- replacement value;

- inflation rate;

- real discount rate;

- conditioning or predictive maintenance models to maximize availability:

- KPI's.

These approaches can be integrated into a single analytical model to determine the best time for bus withdrawal and, consequently, the size of the reserve fleet indexed to the size of the overall fleet, as the first implies the second.

Note that the integrated approach is valid for both new and used buses, through the monetary correction effect. Note also that the analysis herein does not include technological and environmental aspects.

Figure 20 shows the integrative model to evaluate the size of a reserve fleet. This figure synthesizes the above approaches, and have as a goal to give a global idea of the development followed along the paper, including the numerical analysis done. As the Figure 20 indicates, inflation costs and the real discount rate influence the replacement value, the maintenance, and the fuel costs. These costs, in return, are influenced by the maintenance policies practiced, such as scheduled maintenance indicated by the supplier, or conditioning maintenance with or without prediction. The type of maintenance performed by companies affects the buses LCC and, hence, the withdrawal models. Finally, the variables shown in the figure influence the size of the reserve fleet, if the aim is to maximize operational availability.

\section{Conclusions and future developments}

The paper presents an overview of the authors' on-going research into the use of econometric models to determine the most rational time to replace a bus. The economic aspects are guided by indicators associated with acquisition, maintenance, and operation costs, among others. The study presented in this paper enables the equipment life cycle to be monitored.

The paper presents some variations in the most rational time to replace vehicles. Using the MUAI for its calculations, it demonstrates the important influence of some variables, namely inflation and real discount rate, withdrawal value and diesel fuel prices, on the most rational time to replace a bus.

Another aspect emphasized by the paper is the importance of implementing condition-based maintenance policies. This helps to reduce the costs associated with

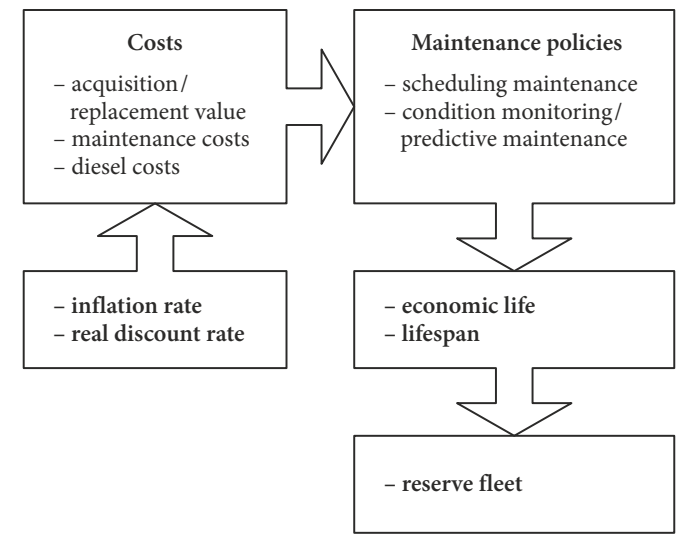

Figure 20. Integrative model for dimensioning a reserve fleet

maintenance, contributing to a decrease in overhead costs and providing an additional guarantee of equipment availability.

In addition, the paper suggests the importance of monitoring the bus lifecycle through oil analysis, as well as the use of a condition-based/predictive maintenance policy, as this influences both the cost of equipment and the size of the reserve fleet.

Finally, it proposes integrating all methodologies into a single model as they all support the decision to replace buses and to determine the size of the reserve fleet.

Future developments include the generalization of models used in other types of buses including the new generation ones. The goal of the urban bus company is the validation of the models presented to the new hybrid and electric buses that the company is buying. This made us the challenge to enlarge the analysis and to develop new econometric models to this new type of buses.

\section{Acknowledgements}

The authors wish to thank Centre for Mechanical Engineering of the University of Coimbra (Portugal).

The authors thank the participation of:

- Prof. Filipe José Didelet Pereira, in drafting and revising it critically for important intellectual content.

- Prof. Joaquim Norberto Pires, in drafting and revising it critically for important intellectual content.

- Prof. Jorge Campos da Silva André, in drafting and revising it critically for important intellectual content.

\section{Funding}

This work was supported by Foundation for Science and Technology (Portugal), project UID/EMS/00285/2013 Centre for Mechanical Engineering of the University of Coimbra (Portugal).

\section{Contribution}

Authors are welcome to declare any involvement in writing a manuscript (e.g. conception and design of the work, 
acquisition of data, or analysis and interpretation of data, drafting the article or revising it critically for important intellectual content, etc.).

\section{Disclosure statement}

The authors declare that not they have any competing financial, professional, or personal interests from other parties.

\section{References}

Amaya, E. J.; Tonaco, R.; Souza, R. Q.; Álvares, A. J. 2007. Sistema inteligente de manutenção baseada em condição para usina hidrelétrica de Balbina, in $8^{\circ}$ Congreso Iberoamericano de Ingeniería Mecánica (CIBIM8), 23-25 Octubro 2007, Cusco, Perú, 1-7. Available from Internet: http://congreso.pucp.edu. pe/cibim8/pdf/12/12-17.pdf (in Portuguese).

André, J. 2008. Probabilidades e Estatística para Engenharia. Editora: Lidel. 600 p. (in Portuguese).

Aoudia, M.; Belmokhtar, O.; Zwingelstein, G. 2008. Economic impact of maintenance management ineffectiveness of an oil and gas company, Journal of Quality in Maintenance Engineering 14(3): 237-261. https://doi.org/10.1108/13552510810899454

Araujo, M. S.; Bezerra, C. A. 2004. Desenvolvimento de componentes para sistemas estocásticos de apoio à decisão, in $I V$ Congresso Brasileiro de Computação - CBComp 2004, 8-12 Outubro 2004, Itajaí, Santa Catarina, Brasil, 101-107. Available from Internet: http://www.ufrgs.br/niee/eventos/CBCOMP/2004/pdf/Engenharia_Software/t170100034_3.pdf (in Portuguese).

Assaf Neto, A. 2014. Finanças Corporativas e Valor. Editora: Atlas. 824 p. (in Portuguese).

Assis, R. 2014. Apoio à Decisão em Manutenção e Gestão de Ativos Físicos. Editora: Lidel. 592 p. (in Portuguese).

Assis, R.; Julião, J. 2009. Gestão da manutenção ou gestão de activos? (Custos ao longo do ciclo de vida), in $10^{\circ}$ Congresso Nacional de Manutenção, 10-20 Novembro 2009, Figueira da Foz, Portugal, 1-19. (in Portuguese).

ASTM E917-17. Standard Practice for Measuring Life-Cycle Costs of Buildings and Building Systems. https://doi.org/10.1520/E0917-17

Beichelt, F. 2001. A replacement policy based on limiting the cumulative maintenance cost, International Journal of Quality \& Reliability Management 18(1): 76-83.

https://doi.org/10.1108/02656710110364459

Bescherer, F. 2005. Established Life Cycle Concepts in the Business Environment - Introduction and Terminology. Laboratory of Industrial Management, Helsinki University of Technology, Finland.

Cabral, J. S 2006. Organização e Gestão da Manutenção: dos Conceitos à Prática. Editora: Lidel. 384 p. (in Portuguese).

Cabrita, C. P.; Cardoso, A. J. M. 2015. Conceitos e definições de falha e avaria nas normas portuguesas de manutenção NP EN 13306:2007 e NP EN 15341:2009, Revista de Manutenção 125(2): 4-9. (in Portuguese).

Campello, R. J. G. B.; Amaral, W. C. 2001. Modeling and linguistic knowledge extraction from systems using fuzzy relational models, Fuzzy Sets and Systems 121(1): 113-126. https://doi.org/10.1016/S0165-0114(99)00175-X

Campos, L. C. D.; Vellasco, M. M. B. R.; Lazo, J. G. L. 2010. A stochastic model based on neural networks, in The 2011
International Joint Conference on Neural Networks, 31 July-5 August 2011, San Jose, CA, USA, 1482-1488.

https://doi.org/10.1109/IJCNN.2011.6033399

Casarotto Filho, N.; Kopittke, B. H. 2010. Análise de Investimentos: Matemática Financeira, Engenharia Econômica, Estratégia Empresarial. Editora: Atlas. 432 p. (in Portuguese).

Chen, D.; Wang, L.; Li, L. 2015. Position computation models for high-speed train based on support vector machine approach, Applied Soft Computing 30: 758-766. https://doi.org/10.1016/j.asoc.2015.01.017

Couellan, N.; Jan, S.; Jorquera, T.; Georgé, J.-P. 2015. Self-adaptive support vector machine: a multi-agent optimization perspective, Expert Systems with Applications 42(9): 4284-4298. https://doi.org/10.1016/j.eswa.2015.01.028

Durairaj, S. K.; Ong, S. K.; Nee, A. Y. C.; Tan, R. B. H. 2002. Evaluation of life cycle cost analysis methodologies, Corporate Environmental Strategy 9(1): 30-39. https://doi.org/10.1016/S1066-7938(01)00141-5

Emblemsvag, J. 2001. Activity-based life-cycle costing, Managerial Auditing Journal 16(1): 17-27. https://doi.org/10.1108/02686900110363447

Farinha, J. M. T. 2011. Manutenção: a Terologia e as Novas Ferramentas de Gestão. Editora: Monitor. 216 p. (in Portuguese).

Feldens, A. G.; Muller, C. J.; Filomena, T. P.; Neto, F. J. K.; Castro, A. S.; Anzanello, M. J. 2010. Política para avaliação e substituição de frota por meio da adoção de modelo multicritério, $A B C u s$ tos, São Leopoldo: Associação Brasileira de Custos 5(1): 61-91. Available from Internet: https://abcustos.emnuvens.com.br/ abcustos/article/view/86 (in Portuguese).

Figueiredo, L. M. J. 2009. Modelo Multicritério de Apoio à Substituição de Equipamentos Médicos Hospitalares: Dissertação para a atribuição do Grau de Mestre em Engenharia Biomédica. Instituto Superior Técnico, Universidade Técnica de Lisboa, Lisboa, Portugal. 100 p. Available from Internet: https:// fenix.tecnico.ulisboa.pt/downloadFile/395139481609/Tese. pdf (in Portuguese).

FTA. 1987. FTA Circular C 9030.1A. US Department of Transportation, Federal Transit Administration (FTA), Washington, DC, US.

Gurney, K. 1997. An Introduction to Neural Networks. CRC Press. $234 \mathrm{p}$.

Hritonenko, N.; Yatsenko, Y. 2007. Optimal equipment replacement without paradoxes: a continuous analysis, Operations Research Letters 35(2): 245-250.

https://doi.org/10.1016/j.orl.2006.03.001

Huang, J.-Y.; Yao, M.-J. 2008. On the coordination of maintenance scheduling for transportation fleets of many branches of a logistic service provider, Computers \& Mathematics with Applications 56(5): 1303-1313.

https://doi.org/10.1016/j.camwa.2008.01.037

ISO 55000:2014. Asset Management - Overview, Principles and Terminology.

ISO 55001:2014. Asset Management - Management Systems - Requirements.

ISO 55002:2014. Asset Management - Management Systems Guidelines for the Application of ISO 55001.

Jin, D.; Kite-Powell, H. L. 2000. Optimal fleet utilization and replacement, Transportation Research Part E: Logistics and Transportation Review 36(1): 3-20. https://doi.org/10.1016/S1366-5545(99)00021-6

Keles, P.; Hartman, J. C. 2004. Case study: bus fleet replacement, The Engineering Economist: a Journal Devoted to the Problems of Capital Investment 49(3): 253-278. https://doi.org/10.1080/00137910490498951 
Khasnabis, S.; Alsaidi, E.; Ellis, R. D. 2002. Optimal allocation of resources to meet transit fleet requirements, Journal of Transportation Engineering 128(6): 509-518. https://doi.org/10.1061/(ASCE)0733-947X(2002)128:6(509)

Korpi, E.; Ala-Risku, T. 2008. Life cycle costing: a review of published case studies, Managerial Auditing Journal 23(3): 240-261. https://doi.org/10.1108/02686900810857703

Leung, F. K. N.; Cheng, A. L. M. 2000. Determining replacement policies for bus engines, International Journal of Quality \& Reliability Management 17(7): 771-783. https://doi.org/10.1108/02656710010336361

Lindholm, A.; Suomala, P. 2005. The possibilities of life cycle costing in outsourcing decision making, in Frontiers of eBusiness Research 2004: FeBR 2004: Conference Proceedings, 20-22 September 2004, Tampere, Finland, 226-241.

Luna, I.; Ballini, R.; Soares, S. 2006. Técnica de identificação de modelos lineares e não-lineares de séries temporais, Revista Controle \& Automação 17(3): 245-256.

https://doi.org/10.1590/S0103-17592006000300001 (in Portuguese).

Makridakis, S. G.; Wheelwright, S. C.; Hyndman, R. J. 1998. Forecasting: Methods and Applications. Wiley. 656 p.

Motta, R. R.; Calôba, G. M. 2002. Análise de Investimentos: Tomada de Decisão em Projetos Industriai. Editora: Atlas. 391 p. (in Portuguese).

Müller, D. 2007. Processos Estocásticos e Aplicações. Editora: Almedina. 276 p. (in Portuguese).

NP EN 15341:2009. Manutenção: Indicadores de Desempenho da Manutenção (KPI). Norma Portuguesa. (in Portuguese).

Oliveira, J. A. N. 1982. Engenharia Econômica: Uma Abordagem às Decisões de Investimento. Editora: McGraw Hill. 172 p. (in Portuguese).

PAS 55-1:2008. Asset Management. Part 1: Specification for the Optimized Management of Physical Assets. British Standards, UK.

PAS 55-2:2008. Asset Management. Part 2: Guidelines for the application of PAS 55-1. British Standards, UK.

Pooyan, N.; Shahbazian, M., Salahshoor, K.; Hadian, M. 2015. Simultaneous fault diagnosis using multi class support vector machine in a dew point process, Journal of Natural Gas Science and Engineering 23: 373-379.

https://doi.org/10.1016/j.jngse.2015.01.043

Raposo, H.; Farinha, J. T.; Oliveira, R.; Ferreira, L. A.; André, J. 2014. Time replacement optimization models for urban transportation buses with indexation to fleet reserve, in MPMM Maintenance Performance Measurement and Management: Proceedings of Maintenance Performance Measurement and Management (MPMM): Conference 2014, 4-5 September 2014, Coimbra, Portugal, 41-48.

https://doi.org/10.14195/978-972-8954-42-0_7

Reis, M. A.; Melo, S. A. B. V.; Duarte, A. A.; Schnitman, L. 2010. A utilização de redes Bayesianas no processo decisório de intervenções em equipamentos, in XVIII Congresso Brasileiro de Automática, 12-16 Setembro 2010, Bonito, Brasil, 5058-5064. (in Portuguese).

Rogers, J. L.; Hartman, J. C. 2005. Equipment replacement under continuous and discontinuous technological change, IMA Journal of Management Mathematics 16(1): 23-36. https://doi.org/10.1093/imaman/dph027

Scarf, P. A.; Bouamra, O. 1999. A capital equipment replacement model for a fleet with variable size, Journal of Quality in Maintenance Engineering 5(1): 40-49.

https://doi.org/10.1108/13552519910257050
Simões, A. S. 2011. Manutenção Condicionada às Emissões Poluentes em Autocarros Urbanos: Diagnóstico por Cadeias Escondidas de Markov: Tese Aprovada em Provas Públicas Para a Obtenção do Grau de Doutor em Transportes. Instituto Superior Técnico, Universidade Técnica de Lisboa, Lisboa, Portugal. 322 p. Available from Internet: http://files.isec.pt/ DOCUMENTOS/SERVICOS/BIBLIO/teses/Tese_Dout_Antonio-Simoes.pdf (in Portuguese).

Sullivan, W. G.; McDonald, T. N.; Van Aken, E. M. 2002. Equipment replacement decisions and lean manufacturing, Robotics and Computer-Integrated Manufacturing 18(3-4): 255-265. https://doi.org/10.1016/S0736-5845(02)00016-9

Tsoukalas, L. H.; Uhrig, R. E.; Zadeh, L. A. 1997. Fuzzy and Neural Approaches in Engineering. Wiley-Interscience. 600 p.

Vey, I. H.; Rosa, R. M. 2004. Utilização do custo anual uniforme equivalente na substituição de frota em empresas de transporte de passageiros, Revista Eletrônica de Contabilidade 1(1): 150-173. https://doi.org/10.5902/198109465890 (in Portuguese).

Vujanović, D.; Momčilović, V.; Bojović, N.; Papić, V. 2012. Evaluation of vehicle fleet maintenance management indicators by application of DEMATEL and ANP, Expert Systems with Applications 39(12): 10552-10563.

https://doi.org/10.1016/j.eswa.2012.02.159

Wijaya, A. R.; Lundberg, J.; Kumar, U. 2012. Robust-optimum multi-attribute age-based replacement policy, Journal of Quality in Maintenance Engineering 18(3): 325-343, Emerald Group Publishing Limited 1355-2511. https://doi.org/10.1108/13552511211265910

Yager, R. R.; Zadeh, L. A. (Eds.). 1992. An Introduction to Fuzzy Logic Applications in Intelligent Systems. Springer. $356 \mathrm{p}$. https://doi.org/10.1007/978-1-4615-3640-6

Zhao, H. 2009. A chaotic time series prediction based on neural network: evidence from the Shanghai composite index in China, in 2009 International Conference on Test and Measurement, 5-6 December 2009, Hong Kong, China, 382-385. https://doi.org/10.1109/ICTM.2009.5413024

Zohrul Kabir, A. B. M. 1996. Evaluation of overhaul/replacement policy for a fleet of buses, Journal of Quality in Maintenance Engineering 2(3): 49-59. https://doi.org/10.1108/13552519610130440 